\title{
PRESTIGIO SIMBÓLICO Y CONTROL EPISCOPAL. LA ESTRATEGIA DEL OBISPO ALONSO RAMÍREZ DE VERGARA FRENTE AL CAPÍTULO CATEDRALICIO DE CHARCAS*
}

\author{
SYMBOLIC PRESTIGE AND EPISCOPAL CONTROL. \\ THE STRATEGY OF BISHOP ALONSO RAMÍREZ DE VERGARA \\ IN FRONT OF THE CATHEDRAL CHAPTER OF CHARCAS
}

\author{
Nelson Castro Flores ${ }^{* *}$
}

\begin{abstract}
En este trabajo se analizan las estrategias implementadas por el obispo Alonso Ramírez de Vergara para dotar de organización y prestigio simbólico a la iglesia catedral de Charcas o La Plata. En este sentido, la promoción del culto a reliquias e imágenes sagradas, así como la elaboración de constituciones o regla consueta, forman partes de estrategias de control y prestigio episcopal. Estas estrategias tuvieron por propósito delimitar y aminorar la autoridad del capítulo catedralicio de La Plata, acrecentada tras varios períodos de sede vacante en la segunda mitad del siglo XVI, y en los que se configuró una dinámica jurisdiccional contraria a las disposiciones tridentinas e incluso a las disposiciones del patronazgo real.

Palabras claves: Capítulo catedralicio, regla consueta, prestigio simbólico, Charcas, jueces consiliarios.
\end{abstract}

This work analyzes the strategies implemented by Bishop Alonso Ramírez de Vergara to provide organization and symbolic prestige to the Cathedral Church of Charcas or La Plata. In this sense, the promotion of the cult of relics and sacred images, and the elaboration of constitutions or regla consueta, are part of episcopal control and prestige strategies. The purpose of these strategies was to delimit and reduce the cathedral chapter of La Plata's authority, increased after several periods of vacant headquarters in the second half of the 16th century, and a jurisdictional dynamic contrary to the Tridentine provisions and even to the provisions of the Royal Patronage.

Key words: Cathedral chapter, consueta rule, symbolic prestig, Charcas, deputy judges.

\section{Introducción}

El estudio de las normatividades y de las instituciones eclesiásticas virreinales ha recibido una fuerte atención en la reciente producción historiográfica. Dentro de este ámbito, se ha destacado el valor documental de las reglas consuetas para el estudio de la legislación eclesiástica (Danwerth, Albani y Duve 2019; Grignani 2009, 2019; Martínez de Sánchez 2008; Terráneo 2011). El interés por este cuerpo normativo fue planteado hace unas décadas por historiadores eclesiásticos. En esta perspectiva, Oviedo (1986) planteó que las reglas consuetas dotaron de estabilidad a la organización de la Iglesia, avanzando, asimismo, en la identificación de la normativa en la que se apoyó la elaboración de estos cuerpos jurídicos del derecho canónico indiano. Como el propio Cavada señaló, este aspecto no fue menor debido a los largos períodos de sede vacante de las diócesis americanas.

Sin embargo, las diócesis americanas contaron con constituciones de erección que replicaron las normativas de las iglesias catedrales españolas, principalmente de la catedral de Sevilla, y que sirvieron de fuentes para la redacción de las posteriores reglas consuetas. Es decir, que desde su erección las diócesis contaron con un conjunto de normativas para el gobierno de las iglesias catedrales. No obstante, estas fueron tardíamente adecuadas al contexto de las diócesis americanas. En la década de 1590, el arzobispo de Lima redactó la denominada Regla Consueta en el marco del sínodo diocesano de 1593 (Grignani 2009). A diferencia de la diócesis de La Plata, el arzobispado

\footnotetext{
* Proyecto UNAM PAPIIT IG 4006619 "Religiosidad nativa, idolatrías e instituciones eclesiásticas en los mundos ibéricos, época moderna", dirigido por el Dr. Gerardo Lara Cisneros.

** Centro de Estudios Históricos, Universidad Bernardo O’Higgins. Programa de Doctorado en Historia, Universidad de Chile. Santiago, Chile. Correo electrónico: ncastrof@yahoo.com
} 
de Lima tuvo una mayor continuidad en el gobierno arzobispal, pues Jerónimo de Loaysa (1548-1575) y Toribio de Mogrovejo (1579-1606) gobernaron en períodos relativamente extensos propicios para aplicar medidas fundamentales para el gobierno eclesiástico (Acosta 1996; Tudini 2018; Grignani 2009); pero en estos largos gobiernos se asentaron prácticas que conflictuaron las relaciones de los prelados con otros sectores de la población, como fue el caso del arzobispo Laoyza en la administración de una encomienda (Acosta 2015).

En el caso del obispado de La Plata, diócesis sufragánea del arzobispado de Lima, los períodos de sede vacante fueron mayores. Desde su erección, en 1553, la diócesis de La Plata tuvo cerca de una década de sede vacante (García 1964). El obispo fray Domingo de Santo Tomás (15631570), entusiasta lascasiano, fue el primer prelado que gobernó efectivamente la diócesis, aunque no exento de conflictos con el cabildo eclesiástico (Hampe 1990; García 1964). Tras su muerte, la sede vacante duró cerca de ocho años, sin embargo, en los hechos, se extendió un poco más porque Alonso Granero de Ávalos (1578-1785) llegó a Charcas en 1582 , a pesar de haber sido designado obispo de la diócesis en $1578^{1}$. Este retraso se debió a que el obispo aprovechó su viaje a Charcas para ejercer sus funciones como inquisidor en la provincia de Nicaragua, usurpando facultades jurisdiccionales privativas del Santo Oficio, además de usar sus poderes para encubrir sus intereses mercantiles (Vallejo 2015, II: 125-139). En La Plata también tuvo un controvertido gobierno episcopal que se conoce por los juicios lapidarios de algunos doctrineros contemporáneos (Álvarez 1998 [1588]; Figueroa 2021). Pero asimismo fue un activo defensor de la jurisdicción episcopal frente a la audiencia de La Plata, en la que tuvo un papel protagónico Domingo de Almeyda (Pérez 2013).

A estos prelados sucedieron Alonso de la Cerda (1587-1592), antiguo provincial dominico en Perú y obispo de Honduras, y Alonso Ramírez de Vergara (1597-1602), respectivamente. En su conjunto, y a diferencia de la diócesis metropolitana, el obispado de La Plata tuvo veintiséis años de sede vacante durante la segunda mitad del siglo XVI. Y este aspecto no deja de tener importancia. Varios miembros del capítulo catedralicio permanecieron por un período superior al de los prelados. Esto permitió que, en sede vacante, el cabildo catedralicio pudiera impactar en las dinámicas de la diócesis charqueña, es decir, y a pesar de (y con) sus conflictos internos, aquella le permitió articular una estrategia de reproducción social en la que se evidenció a una congregación (el deán y cabildo) y un espacio jurisdiccional (la iglesia catedral y la diócesis sede vacante). Además, con esto el cabildo eclesiástico tuvo un lugar "en el régimen de contrapesos del sistema eclesial" (Schwaller 2017: 21), para retomar una afirmación de Schwaller a propósito del cabildo novohispano en el siglo XVI. De esta manera, el cabildo catedralicio adquirió una fuerte presencia en la catedral, al igual que otros cabildos en el espacio americano, sin embargo, como señala Leticia Pérez (2005: 365), no debe descuidarse que "la legislación conciliar creó una tendencia contraria a ellos", sobre todo si se considera que hasta el siglo XV los miembros del cabildo "estaban exentos de la jurisdicción del obispo, quedando sometido a la del propio cabildo" (Díaz 2012: 79). Aunque los prebendados estaban obligados a reconocer la jurisdicción episcopal, sin embargo, el obispo o su provisor no podía encausarlos judicialmente sin la concurrencia de jueces adjuntos (Coello de la Rosa 2011). Anualmente el deán y cabildo, aún en sede vacante, procedió a elegir a estos jueces denominados consiliarios como se verá más adelante.

En este contexto se desarrolló el gobierno episcopal de Alonso Ramírez de Vergara. Los años de formación en el Colegio Mayor San Bartolomé de Salamanca, entregaron a este prelado, al igual que a todos quienes pasaron por los colegios mayores de la Península, una formación en saberes "encaminados a la gestión y la administración de un poder, ya fuera este espiritual, temporal o una mezcla de ambos" (Lario 2019: 29). La carrera eclesiástica de varios colegiales estuvo caracterizada por la ocupación de canonjías en la Península y obispados en las Indias. Precisamente este fue el recorrido de Alonso Ramírez de Vergara, "Doctor teólogo, eminentísimo en lo escolástico y positivo", quien fue canónigo magistral en Málaga antes de ser nombrado obispo de La Plata (Ramírez del Águila 2017: 378).

Aunque el gobierno del obispo Alonso Ramírez de Vergara no sobrepasó el lustro, sin embargo, tuvo fuertes repercusiones en la organización de la iglesia catedral de La Plata, en la fijación de aranceles y en la dotación de imágenes y reliquias devocionales. En estas acciones se habría evidenciado el propósito de fortalecer el poder y prestigio en una diócesis en la que la sede vacante permitió afianzar las pretensiones corporativas del cabildo 
catedralicio, ocasionando contrariedades no solo a anteriores obispos, sino que también al presidente de la audiencia de La Plata (Bridikhina 2007: 72 y ss.). Este no fue un fenómeno exclusivo de la diócesis charqueña, sino que este se extendió al conjunto de las demás diócesis americanas (Garavaglia y Marchena 2005), como lo ha demostrado Pérez $(2013$; 2016a) a propósito de los conflictos y disputas entre obispos y cabildos eclesiásticos por los seminarios conciliares.

En la perspectiva de este artículo, el obispo Alonso Ramírez de Vergara reprodujo una estrategia social de fortalecimiento del poder episcopal tendiente a aminorar el protagonismo del cabildo eclesiástico en la diócesis charqueña. Esta estrategia no puede separarse de las orientaciones del Concilio de Trento respecto del fortalecimiento del poder episcopal, recogidas en las disposiciones de los concilios provinciales limenses de 1567 y 1583 , además de las políticas regias que direccionaron el curso de acción del gobierno episcopal en las Indias, particularmente a partir de la década de 1570 (Merluzzi 2014; Pérez 2014).

Esto se tradujo en el reforzamiento del prestigio simbólico de la iglesia catedral mediante la dotación de reliquias e imágenes milagrosas, aspecto que se analiza en el segundo apartado de este artículo. Para el occidente medieval algunos autores observaron la relación de las reliquias en el marco de una dinámica de mercancías sagradas que redundaban en el prestigio de un obispado (Geary 1991). Para el caso novohispano, Rubial consideró que esta promoción episcopal de imágenes milagrosas fue "parte fundamental de su apropiación de las ciudades como centros episcopales", agregando que estas "manifestaciones milagrosas fueron un importante vehículo de expresión de alianzas y conflictos entre los distintos cuerpos y autoridades en las ciudades y regiones del virreinato" (Rubial 2017: 218). Desde el siglo XVI, esta estrategia fue coherente con el monopolio simbólico episcopal que se impuso desde el concilio de Trento respecto de reliquias e imágenes y, en sentido más amplio, con las estrategias de clericalización del mundo sobrenatural (Campagne 2002). En el virreinato peruano, esta perspectiva fue asumida en los concilios provinciales limenses que enfatizaron el control episcopal sobre la autentificación y circulación de reliquias (Vargas 1951), además de promover una pastoral centrada en la imagen (Castro, Chacama y Mir 2009; Sanfuentes 2019).
Una segunda dimensión de la estrategia del obispo fue intervenir en la autonomía corporativa del cabildo catedralicio, largamente cultivada en sede vacante, imponiendo nuevas constituciones y estatutos a la iglesia catedral de La Plata. Sobre esto ha existido una confusión entre diversos autores que señalan que las constituciones de 1597 derivaron de un sínodo diocesano convocado por el obispo Alonso Ramírez de Vergara (Dussel 1983; García 1964; Martínez de Sánchez 2013). Sin embargo, como se analiza en el tercer apartado de este trabajo, las constituciones o regla consueta de Alonso Ramírez de Vergara fueron el resultado de la primera visita pastoral que encabezó este obispo.

\section{La acción del cabildo en sede vacante}

De acuerdo con Iogna-Prat, los polos eclesiales (iglesias, cementerios, conventos, hospitales, etc.) proporcionaron "una buena parte de la electricidad estática necesaria para el funcionamiento del tejido urbano" de las ciudades modernas (Iogna-Prat 2016: 186). La sede episcopal de La Plata no estuvo exenta de este policentrismo religioso en el que la iglesia catedral se constituyó en el espacio por excelencia del culto y del despliegue de la jerarquía eclesiástica premunida de dignidad. El prelado y los miembros del cabildo, señala el jurista Juan de Solórzano, constituían "Iglesia, i capitulo". Y este es un aspecto que no se debe desconsiderar. La manera de concebir la iglesia heredó, junto con la de orden jerárquico, una concepción en la que se insistió "en la visibilidad de la iglesia, incluso en su 'monumentalidad' inducida por la metonimia iglesia-edificio/iglesia-comunidad y la necesaria confusión continente/contenido" (Iogna-Prat 2016: 164). No obstante, no se debe descuidar la estrecha relación de la jerarquía eclesiástica con la monarquía.

De acuerdo con el patronazgo real, arzobispos y obispos se proveían por presentación real ante el papado. En el caso de los miembros del capítulo catedralicio (dignidades, canónigos, racioneros y medios racioneros), estos se proveían "por nuestra prouisión real librada por nuestro Consejo Real de las Yndias y firmada de nuestro nombre por virtud de la qual el arçobispo o obispo de la iglesia donde fuere la dicha dignidad, canonjía o ración le haga collación y canónica ynstituçión"2. Además, la disposición real estableció que esta colación debía fijarse por escrito, firmada y sellada por el prelado, sin esto no tenía efecto la posesión y, 
por tanto, tampoco se podía entregar los frutos y emolumentos de la prebenda. En la práctica, el deán y cabildo asumió esta función en los períodos de vacancia de la silla episcopal. Como aconteció con el doctor Francisco Márquez de Sotomayor quien presentó ante el cabildo eclesiástico

\begin{abstract}
"vna provisión real de su Magestad en que le haze merced de le presentar y promosión a la dignidad de Deán de esta santa iglesia y los títulos de sus órdenes y grados bachiller, licenciado y dotor visto por los dichos Deán y Cabildo sede vacante"3.
\end{abstract}

\section{Cada uno de los capitulares tomó}

\begin{abstract}
"por sí la dicha provisión real y la besaron y pusieron sobre sus cabeças, diçiendo que la obedesçían y obedesçieron como provisión real y carta de su señor y rey natural a quien Dios Nuestro Señor guarde muchos años y mandaron que haga la solemnidad del juramento conforme al Santo Concilio de Trento y hecho proveerán conforme a derecho" 4 .
\end{abstract}

Una vez concluido este procedimiento el presentado ingresaba a la sala del cabildo, o donde estuviesen reunidos, y procedía a realizar el juramento establecido por el Concilio de Trento, tras ello,

“el dicho Deán y Cabildo vnánimes y conformes dixeron que reçibían y reçibieron al dicho dotor don Francisco Márques de Sotomayor por deán de esta santa iglesia conforme a la provisión real y mandavan y mandaron se le haga la collación y canónica institución de la dicha prevenda y dignidad de dean de esta santa iglesia".

El acto concluía con la firma y sello correspondiente.

Para un adecuado funcionamiento del culto, así como para la administración de las iglesias catedrales, se debía contar con un número adecuado de capitulares señalados en la correspondiente erección. De acuerdo con la disposición de patronazgo real, aquellos debían ser preferentemente letrados, con experiencia en las iglesias catedrales y en el servicio del coro y del culto divino ${ }^{5}$. Además, la misma disposición contemplaba cuatro canonjías: doctoral que debía ser ejercida por un jurista letrado; magistral que debía ser ejercida por un teólogo; canonjía lectoral a cargo de un teólogo; y canonjía penitenciaria que podía ser asumida por un teólogo o un jurista. En el caso de la iglesia catedral de La Plata, el obispo fray Tomás de San Martín estableció, en 1553, y siguiendo el modelo de la catedral de Sevilla, que el capítulo estaba compuesto por las siguientes dignidades: deán, arcediano, chantre, tesorero y maestreescuela; además, estableció cinco canonjías y cinco prebendas; por último, el capítulo se completaba con seis raciones enteras (García 1964: 55-57) ${ }^{6}$.

Por algunas razones, no siempre se pudo contar con la totalidad de los capitulares. Aunque en la erección de 1553 se instituyeron seis porciones o raciones, sin embargo, estas se suspendieron hasta que la iglesia catedral tuviera las rentas necesarias para solventar el gasto. Más aún algunos miembros del capítulo catedralicio tuvieron largos períodos de ausencia que dificultaron el funcionamiento del culto divino y la administración de la iglesia catedral. En 1567, el obispo Domingo de Santo Tomás informó que
"arcediano y chantre nunca an ydo a la iglesia; el chantre por ser muy viejo que está en está çiudad de los Reyes, inútil el oficio, y así lo a perdido ya por auer diez años que está proueido y no auer ydo; el arcediano a otro tanto tiempo y está en España, dicen que a intentado muchas veces renunciar y aun no con modo muy lícito"7.

La falta de estas dignidades no permitía el adecuado funcionamiento del coro y la realización de visitas. Además, el obispo observó que los canónigos permanecían por poco tiempo, el necesario para satisfacer sus intereses, y la falta de aquellos perjudicaba el servicio de la iglesia catedral. Esta situación se complicaba porque las disposiciones reales permitían al obispo nombrar solo a cuatro clérigos que cumpliesen los oficios de los prebendados en el coro y altar. Por lo que el obispo solicitó que se pudiese suplir la ausencia de cualquier prebendado, con cargo a la prebenda, además de restringir el período de ausencia de los capitulares para no perjudicar el servicio de la catedral.

En los primeros años de la década de 1580 , el obispo Alonso Graneros de Ávalos señaló que 
la erección de la iglesia catedral no se encontraba cumplida, pues faltaba proveer a seis racioneros, además, había cuatro prebendas vacantes una "canongía por muerte del canónico Pedro de Arzeo, y la thesorería por muerte de Antonio Sánchez de Velis, y el deanadgo por muerte del doctor don Francisco Urquiçu y el arcedianato por absencia del doctor don Hernando Palacios Aluarado"8. Estos prebendados formaron parte de los capitulares nombrados entre las décadas de 1560 y 1570 . Algunos de estos tuvieron fuertes enfrentamientos con el obispo Domingo de Santo Tomás, pero también se vieron enfrentados entre sí. Fue el caso de Francisco de Urquizu y Fernando de Palacios. Ambos tenían una carrera en la institución catedralicia.

Francisco de Urquizu fue nombrado maestreescuela de la catedral de Lima ${ }^{9}$, cargo que juró en 1568 , pero que mantuvo por un breve período porque en 1570 ya no figura entre los prebendados del cabildo limeño (Bermúdez 1903). El deán Francisco de Urquizu fue nombrado comisario del Santo Oficio en el distrito de La Plata (Medina 1887; I: 43). A fines de la década de 1570, Fernando de Palacio Alvarado quien fue procesado por la Inquisición "por cierta polémica que tuvo con sus colegas sobre los que se salvaban de la lei natural" (Medina 1887; I: 188). De acuerdo con un testimonio, las diligencias que se hicieron contra Fernando de Palacio Alvarado:

\begin{abstract}
"era de raçón de cierta diferencia que tuvo con Urquiza, deán de los Charcas y comisario del Sancto Officio, al qual le dixo el ynquisidor Cerezuela, que Alvarado piensa que nos espantamos de Alvarado, más Alvarado ay por las caballerizas, y al mismo arcediano oyó quexarse de los inquisidores desta ciudad, por habérsele hecho venir de la ciudad de la Plata a esta y tenídole preso muchos días" (Medina 1887; I: 282).
\end{abstract}

Fernando de Palacio Alvarado era beneficiado en Limpias (Castilla) al momento de ser propuesto a una canonjía de La Plata. En 1559, Fernando González Cuesta, obispo electo de La Plata en 1559, propuso al bachiller Fernando de Palacio Alvarado a la canonjía en consideración "que en dicha yglesia está vaco vn canonicato por fin e muerte del bachiller Diego de Burgos"10. Hacia la década de 1560 , obtuvo el grado de doctor quizás en una universidad de la Península, pues en la cédula de nombramiento de arcediano de La Plata se antepuso el grado de doctor ${ }^{11}$. En la fecha del nombramiento, el ahora doctor Francisco de Palacio Alvarado se encontraba en España, ya que una cédula prorrogó la licencia de su estadía ${ }^{12}$. A su regreso, en 1568, fue nombrado provisor por el obispo Domingo de Santo Tomás.

A inicios de la década de 1580, el capítulo catedralicio se redujo a dos dignidades y cuatro canónigos. Esta situación repercutió en el servicio del culto en la catedral al que estaban obligados los capitulares. De acuerdo con el obispo, esto quedaba en evidencia en los días festivos en los que se debían vestir para el altar "y hauiendo de hacer caperos faltan otros tres para tomar las capas que conuiene y no ay quien haga el oficio en el coro, sino dos cantores porque aún los mochachos se ocupan en el ofiçio de acólitos, así que no se puede hacer con tan pocos [...] el ofiçio diuino en fiestas con la decencia que conuyene"13. Ciertamente que la falta de capitulares dificultó la realización del culto en la iglesia catedral de La Plata con el boato y solemnidad correspondientes. Pero también los capitulares resultaban imprescindibles para la administración de la iglesia catedral y para el gobierno de la diócesis en sede vacante. Las prebendas vacantes fueron ocupadas posteriormente, con excepción de la de arcediano. Hacia 1587, el capítulo catedralicio de La Plata estaba compuesto por los siguientes miembros:

\section{Deán: Francisco Márquez de Sotomayor (1587 - ¿1592?) \\ Chantre: Diego Felipe de Molina (1578-1608) \\ Tesorero: Francisco Vásquez (1583) \\ Maestreescuela: Juan de Larreategui \\ Canónigos: Tomás López, Bartolomé de \\ Perea, Pedro Bravo y Antonio Baptista $(1583-1600)^{14}$.}

A inicios de la década de 1590 se despachó presentación para racioneros de la iglesia catedral a Juan Cáceres, Antonio Lobato y Lorenzo Sánchez de Ocaña conforme con la erección de la iglesia catedral, el primero no tomó posesión del cargo ${ }^{15}$. En esta misma década también se aumentó el número de canónigos, pasando de cuatro a ocho, con la designación de Diego de Trejo, Joan Sanz, Diego de Alarcón y Domingo de Almeyda. Estos 
canónigos fueron presentados a canonjías que no habían tenido propietarios, por lo que se les designaba conforme con la erección, con excepción del nombramiento de Domingo de Almeyda en el que se señaló que su presentación se hacía porque la canonjía "está vaca por no la hauer ydo a seruir Juan de Resa presentado a ella"16. Junto con esto, hubo casos en que la vacante ya sea por promoción, dejación o muerte no fue rápidamente atendida. En el obispado de La Plata la dignidad de arcediano estuvo vacante por un extenso período.

En 1591, la audiencia de Charcas propuso a Gonzalo de Alarcón, provisor del obispado, para "la dignidad de Arçediano de esta Santa Iglesia que a 10 años no asiste en ella Arçediano" (Real Audiencia 2007; X: 69[3-II-1591). Pero esta recomendación no contó con la aprobación real. En ese mismo año, "se despachó presentaçión de la persona del licenciado Bartolomé Alonso para el arcedianadgo de la iglesia de los Charcas que está vaca por dexación de don Fernando Palacios Aluarado"17. Sin embargo, en 1595, finalmente fue presentado el bachiller Gonzalo de Alarcón, tesorero de la iglesia catedral de Guatemala, para el arcedianato de la catedral de Charcas ${ }^{18}$. No era un desconocido para los miembros del cabildo charqueño. Llegó como emisario del obispo Alonso de la Cerda y fue designado provisor por el deán y cabildo en sede vacante. Las actas capitulares registran su presencia desde $1597^{19}$. También hubo casos de largas ausencias, aunque autorizadas, de capitulares que realizaron gestiones en la Península. El chantre Diego Felipe de Molina, el más antiguo capitular del cabildo, se ausentó entre 1596 y 1602. De acuerdo con un acta inconclusa del cabildo, "el señor chantre está determinado de yrse de nouenta y seis a los reynos de Hespaña y es razón se le dé poder para todos los negoçios tocantes a esta santa iglesia" ${ }^{20}$. Aunque se le despachó cédula el 6 de abril de 1601 para que él, y sus criados, zarpasen a las Indias, sin embargo, no pudo hacer efectivo ese viaje hasta el año siguiente ${ }^{21}$.

En el caso que la iglesia catedral contara con menos de cuatro capitulares residentes, ya sea porque estos estaban ausentes o las prebendas vacantes, el prelado podía elegir a cuatro clérigos para que "sirvan el coro, altar e Iglesia" a cuenta de las respectivas prebendas de los ausentes o vacantes. Esta designación no traía consigo ninguna titularidad para los clérigos designados, "sino ad nutum ad mobible [que a voluntad puede ser removido] y no tendrán silla de beneficiados en el choro ni entrarán ni ternán boto en el cauildo" 22 . Estos cargos no implicaban una prebenda eclesiástica colativa -es decir, conferida canónicamente y en propiedad-, por lo que se podía proceder sin ningún inconveniente a la remoción del designado. Esto también se aplicó en el caso de la autorización para decir misas en el altar mayor de la iglesia catedral. En 1596, se autorizó a los dos racioneros en ejercicio a decir estas misas rezadas o cantadas porque no había suficientes altares en el templo, pero se señaló que esto se prolongaría hasta que no se proveyese lo contrario por parte del deán y cabildo; además, se remarcó que esta licencia no implicaba que los racioneros adquirieran algún tipo de posesión y que se otorgaba a ellos de manera individual y no a los racioneros en general ${ }^{23}$.

En la primera mitad del siglo XVII, Juan de Solórzano ofreció una sistematización jurídica respecto del gobierno espiritual y las cosas eclesiásticas en Indias. En lo referido al cabildo, siguiendo la sentencia de San Jerónimo, señaló que este era el senado de las iglesias catedrales, agregando que sucedía en la jurisdicción y administración ordinaria de los obispos, pero no en la jurisdicción delegada por el Pontífice ni en la dignidad episcopal (Solórzano 1648: 601). No obstante, señaló algunas medidas que imponían una gradualidad en la sucesión de esta jurisdicción, p. e., la realización de visitas una vez transcurrido un año del comienzo de la sede vacante. En opinión de Solórzano, en virtud del Patronazgo era obligación de "nuestros Católicos reyes, en mirar, encaminar, i favorecer las cosas de las Iglesias, mas en Sedevac[an]te, do[n]de por estar viudas, i faltas de Pastor, debe ser mayor el desvelo, amparo, i proyección del Patron dellas" (Solórzano 1648: 613). Pero esto fue fuente de mayores disputas jurisdiccionales. En el período de sede vacante fueron frecuentes los conflictos entre el presidente de la audiencia, quien actuaba como vicepatrón, y el cabildo sede vacante de La Plata. Los miembros de este último se encontraron más tentados de defender la potestad jurisdiccional que las reformas tridentinas habían reducido en provecho del fortalecimiento de la potestad episcopal, como se ha señalado para otras diócesis peninsulares (Fernández 2010; Rico 2019). También fueron constantes los enfrentamientos del cabildo con los prelados. Aspecto que se evidenció fuertemente en el gobierno del obispo Domingo de Santo Tomás quien no solo se enfrentó al cabildo eclesiástico, 
sino que también a un sector mayoritario de la audiencia de Charcas (Hampe 1990: 376).

Entre las dos últimas décadas del siglo XVI, el obispado de La Plata tuvo dos períodos de sede vacante: entre 1585 y 1589 , por muerte del obispo Alonso Granero de Ávalos; y, entre 1592 y 1596, por fallecimiento del obispo Alonso de la Cerda ${ }^{24}$. ¿Qué implicaciones tuvo la sede vacante en el ámbito del obispado? En 1585, el deán y cabildo de la iglesia catedral procedió a declarar de manera unánime el obispado "en sede vacante por muerte y fallecimiento del susodicho señor Ilustrísimo Alonso Graneros de Ábalos", procediendo a designar, en la misma sesión, al canónigo Bartolomé Perea provisor y vicario general de la diócesis a quien "le dieron y concedieron plenaria jurisdiçión exçepto [en] causas de capitulares y provicarías y visitas" 25 . Esta restricción iba en la línea de resguardar las facultades corporativas, si se permite este anacronismo, de los miembros del cabildo eclesiástico en sede vacante. En esta perspectiva, se debe entender también el acuerdo del mismo cabildo, realizado el 10 de mayo de 1587, en orden a que los capitulares recibiesen los salarios correspondientes a sus cargos y funciones en caso que fuesen apresados por orden de la real audiencia, o del mismísimo virrey, "por causa de la jurisdiçión eclesiástica e defensa de la inmunidad de la iglesia" 26 , sin importar que el lugar de detención fuese la ciudad de La Plata, o cualquier otro lugar, incluido los reinos de España. Este es un aspecto no menor. El acuerdo del cabildo insistió en que la defensa de la inmunidad eclesiástica podía enfrentar a los capitulares con otras jurisdicciones, con el riesgo de enfrentar la cárcel. Además, el acuerdo contravenía lo estipulado en la propia erección de la catedral que establecía que los miembros del cabildo debían estar presentes en la catedral para percibir los salarios correspondientes a sus funciones, incluida la parte correspondiente a los diezmos. Sobre esto último, en 1585, una cédula real insistió en que los prebendados asistiesen a la catedral para atender el culto divino y el debido ornato de la iglesia; en caso de ausentarse sin licencias, o por un tiempo mayor al autorizado, se ordenó cesar las respectivas prebendas ${ }^{27}$.

En 1592, el obispado nuevamente se encontró en sede vacante. En la sesión del 4 de marzo de ese año, se comunicó al deán y cabildo el fallecimiento del obispo Alonso de la Cerda "atento a lo qual la jurisdicción eclesiástica pertenesçe a su señoría y así lo declararon y en consequençia dello declaran estar vacante este obispado y conpeter a su señoría la juridiçión y tomaban y tomaron en sí la juridisçión del dicho obispado y gobierno de él y así lo declararon" 28 . Aquí cabe observar que la designación singular "su señoría" se refiere al deán y cabildo en tanto congregación ${ }^{29}$. Precisamente, en esta, y no en sus miembros de manera individual, recayó la jurisdicción eclesiástica en caso de sede vacante. En virtud de esto, el deán y cabildo nombró a un provisor y vicario general del obispado; en este caso fue el licenciado Gonzalo Alarcón, pero a quien no se entregó jurisdicción plenaria como aconteció con anterioridad. En este caso, el deán y cabildo reservó para sí "los negocios de gobernación del obispado y probeymiento de dotrinas y dar cartas generales de excomunión y negocios de los señores capitulares y los señalaron lo qual se entiende por el tiempo que fuere la voluntad de su señoría y declaran que pueda dar cartas generales de excomunión" ${ }^{30}$. En sede vacante, el deán y cabildo recobraba algunas facultades propias de la jurisdicción episcopal. Por eso que entregaba al provisor y vicario general facultades limitadas, e incluso no le permitió inmiscuirse en asuntos que afectaban directamente al cuerpo capitular, además de fijar a voluntad la duración del nombramiento. En este sentido, el provisor y vicario general se subordinaba a los dictámenes del capítulo catedralicio.

Además, la sede vacante dejaba sin efecto los nombramientos realizados por el obispo, asimismo, estos oficiales quedaban expuestos a juicios de residencia, debiendo dar "fianças de lo juzgado y sentenciado y no dándolas se les secuestren sus bienes y traygan a esta cibdad"31. De acuerdo con el derecho canónico, la jurisdicción de un oficial designado por un prelado, particularmente la de un provisor y vicario general, concluía tras la muerte de aquel "pues su jurisdiccion muere enteramente con aquel de quien era emanacion" (André, Romo y Pastora 1848; IV: 347). Aunque la remoción de los oficiales designados por el obispo se ajustó a derecho, sin embargo, estas acciones permitieron al deán y cabildo retomar el control del gobierno del obispado transitoriamente en mano del prelado y de sus oficiales. Entre otros aspectos, la sede vacante posibilitó a los capitulares intervenir directamente en las dinámicas de la clerecía. Para esto recurrieron a disposiciones del segundo concilio limense, y cédulas del mismo tenor, respecto de la reformación del clero $^{32}$. Además, las visitas fueron instrumentos efectivos para controlar el comportamiento de 
la clerecía, y de la población en general, aunque aquellas abrieron el espacio a abusos y excesos por parte de los visitadores. Donde hubo mayores dificultades fue en el control de las órdenes religiosas y de la vida conventual. Aunque la ampliación de la jurisdicción ordinaria, experimentada tras el Concilio de Trento, también se extendió al mundo conventual, sin embargo, hubo mayores dificultades para el reconocimiento de esta jurisdicción, como lo señala el obispo Gaspar de Villarroel en el siglo XVII (Villarroel 1738; I: 502 y ss.). En sede vacante, un problema fue determinar si el convento de monjas estaba bajo la jurisdicción del ordinario, sin esto no se podía nombrar vicario. Como esta situación no constaba expresamente a algunos prelados, el chantre Diego Felipe de Molina no votó a favor de la propuesta de nombrar vicario para las monjas. De la misma opinión fue el canónigo Bartolomé Perea. Otro capitular señaló que las monjas estaban bajo la jurisdicción del ordinario y que el visitador del obispado debía actuar como vicario de las monjas. Efectivamente, el convento de Nuestra Señora de los Remedios reconoció la obediencia al deán y cabildo sede vacante, lo que abrió un juicio entre este convento y los agustinos de La Plata (Real Audiencia de La Plata 2007; III: 525 [31-VIII-1587]) ${ }^{33}$. En lo que respecta al visitador, los demás capitulares fueron de opinión de nombrar un vicario distinto, para ello se aprobó al canónigo Domingo de Almeyda a quien se le otorgó jurisdicción plenaria en causas de justicia y reformación ${ }^{34}$.

Pero la visita no fue el único instrumento de control del clero con que contaba la sede vacante. También se podía recurrir a otros procedimientos para poner atajo a comportamientos que eran muy recurrentes en la clerecía. En 1586, el deán y cabildo dispuso que todos los clérigos del obispado, y los que también llegaren posteriormente, debían ser "examinados y sabrá si saben las ceremonias de la misa conforme a la bula de su Santidad y que no digan misa si no fuere con la licencia de la persona que sus mercedes señalaren para el examen de los dichos clérigos" 35 . Probablemente, la bula que los capitulares adujeron fue la Quo Primum Tempore (1570) de Pío V con la que se aprobó el Misal Romano, derivado del Concilio de Trento, con el que se unificó el rito romano de la misa (Ornelas 2016).

En 1596, el cabildo denunció que en el obispado

"ay y a abido vn abuso grande contra lo dispuesto por el santo concilio de Trento y limense de nombrarse los clérigos liçençiados, dotores y bachilleres no lo siendo de que es causa que con semejantes títulos encubran su ignorancia y poco sauer en deseruyçio de Dios, por tanto, se convendrá que todos exsiban los títulos y que nadie se nombre más del grado que tubiere" 36 .

El edicto obligó a los clérigos de la ciudad a mostrar sus títulos, al igual que cada uno de los capitulares, y los demás clérigos debían entregar las copias correspondiente a los vicarios de los partidos para que los remitiesen a la catedral.

La forma en la que el deán y cabildo condujo el gobierno del obispado en sede vacante fue objeto de algunas críticas. En 1590, una cédula real señaló "que, en la sede vacante de este obispado, por muerte del doctor Granero de Ábalos, huuo muy mal gouierno, y muchos bandos entre los prebendados", advirtiendo "que quando subçediere muerte del prelado ese cauildo tenga mucha quenta en el gouierno y administraçión de las cosas spirituales porque lo contrario no obligue dar otra orden" ${ }^{37}$. Esta cédula respondió a las serias críticas que acerca de la sede vacante realizó la audiencia de Charcas en una carta fechada en $1587^{38}$. Según Juan López de Cepeda y Juan Díaz Lopidana, presidente y oidor de la audiencia respectivamente, los prebendados del cabildo de La Plata asumían prerrogativas espirituales y temporales que no les correspondían, además, alentaban la creación de bandos que dificultaban las relaciones entre los capitulares y entre la clerecía. Asimismo, los miembros de la audiencia informaron que los visitadores eclesiásticos incurrían no solo en excesos contra indios y españoles, sino que también intervenían en asuntos propios de la jurisdicción real. La crítica al gobierno del obispado en tiempos de sede vacante no era nueva. Los prelados del concilio provincial limense de 1583 fueron enfáticos en denunciar las consecuencias que tuvo la sede vacante, para las diócesis del arzobispado, por el afloramiento de bandos y parcialidades que incidían negativamente en los nombramientos y en la falta de disciplina del clero $^{39}$. Sobre estos aspectos también hubo críticas de la audiencia de Charcas. El licenciado Juan López de Cepeda señaló, hacia septiembre de 1591, que recibió diversas denuncias contra clérigos que no contaban con los méritos suficientes para ser nombrados curas, pero que habían sido promovidos por el obispo a instancias de los miembros del cabildo que sacaban provecho de su delicado estado de salud ${ }^{40}$. 
Las críticas de la audiencia pueden dar una visión parcial respecto de los problemas que se originaron en la sede vacante. Algunos miembros del capítulo catedralicio fueron conscientes de las tensiones que se suscitaban en estos períodos, principalmente cuando se expresaban los pareceres que fundamentaban alguna votación. El tesorero del cabildo eclesiástico de La Plata llegó a plantear "que conviene que los cabildos se hizieren de aquí adelante cerca de lo que en tales cabildos se propusiere los señores deán y cabildo voten afirmando o negando y así cuenten el voto sin expresar razones o causas porque en las vacantes pasados obo muchos enojos y pesadumbres" ${ }^{41}$. En esta propuesta hubo un intento de aminorar el efecto negativo que pudo haber tenido más de alguna discusión entre los capitulares. Sin embargo, limitarse a una simple votación afirmativa o negativa frente a un asunto propuesto por quien presidía el cabildo no resolvía los problemas. No solo porque la emisión del parecer y voto seguía una regla jerárquica, comenzando por la más alta dignidad y terminando con el racionero de menor experiencia, sino porque entre los capitulares hubo afinidades, lazos y lealtades que sobrepasaban el marco de la sala capitular y del coro. En algunas ocasiones, esas alianzas permitieron enfrentarse a una alta dignidad.

Por enfermedad y posterior vacancia del deanato, el doctor Diego Felipe de Molina, chantre de la iglesia catedral, asumió la presidencia del cabildo sede vacante. A partir de agosto de 1585 desempeñó esta dignidad, tras haber sido maestreescuela de la iglesia catedral desde 1578, pero, en 1593 , se pretendió cuestionar las aptitudes musicales del doctor Diego Felipe de Molina para desempeñar la dignidad de chantre. El tesorero, quien presidió ese cabildo, sostuvo "que conforme al capítulo de la ereçión de esta Sancta Iglesia el chantre de ella tiene obligaçión de ser perito yn utso que cantu para levantar las antífonas y entonar los himnos y porque el señor chantre no sabe cantar canto llano ny canto de órgano", por lo que no podría ser "admitido la dicha chantría por ser como es contra la dicha erection por no saber cantar" 42 . Esta falta de habilidad musical, según el tesorero, provocó diversas confusiones en el coro por lo que solicitó que el chantre pusiera "persona ydónea y sufiçiente para que supla las faltas que ay y le pague de su renta y que esta persona que pusiere sirva el dicho oficio en tanto que su merced lo aprende y lo sabe para lo hazer por su persona y este es su boto y paresçer" ${ }^{43}$. Efectivamente, la erección de la iglesia catedral estipuló que a la chantría o cantoría no podía ser presentado quien no fuera in musica in vtroque cantu doctus ${ }^{44}$. Según el cabildo, el chantre no era perito ni en música ni en canto llano ni de órgano. En la constitución de erección de la iglesia catedral, esta pericia era imprescindible, además, porque los indios se dejaban llevar por la armonía de la música y del canto, del mismo modo que, según el mismo documento, en antaño sacrificaban cantando a los demonios. La propia audiencia de La Plata había presentado, en 1585, al canónico Tomás López quien por su "habilidad de boz y música, $[\ldots]$ se empleará muy bien en él la de chantre a esta mesma Yglesia, que está vaca al presente por fallesçimiento de don Francisco Franco" (Real Audiencia 2007; X: 14 [15-II-1585]). Sin embargo, la carrera eclesiástica del chantre no estuvo vinculada a sus dotes musicales, sino que al reconocimiento que gozaba como letrado y teólogo formado en Salamanca ${ }^{45}$. De ahí que, en 1594, la real audiencia reconoció "que la dignidad e prenda que tiene y otra mayor están en él bien empleado" (Real Audiencia 2007; X: 136-137 [3-IV-1594]). El cuestionamiento a las habilidades del chantre planteó la necesidad de colocar un sochantre que supliera la pericia musical del chantre. Como se verá más adelante, este aspecto se incorporó en la regla consueta del obispo Alonso Ramírez de Vergara.

No obstante, la medida propuesta en el cabildo no menguó la relación conflictiva del chantre con algunos miembros del capítulo catedralicio. En carta remitida al virrey, Diego Felipe de Molina insistió en los riesgos que experimentó "por administrar rectitud de justicia y por esta disentir de mis compañeros entiendo", llegando "a tanto aborresçimyento de los capítulos que determinaron darme vna gran pesadumbre en castigo de la que ellos reciben en serles opuesto" 46 . Los capitulares impidieron al chantre dar el sermón en la fiesta de Santo Tomás de Aquino, con amenazas de censuras y aprensión, y "así lo hizieron con cierta color de examen y licencia". Tampoco las relaciones del chantre mejoraron con sus antiguos compañeros. De acuerdo con la Audiencia, Juan de Larrategui deán de la iglesia de La Plata, y anteriormente maestreescuela cuando Diego Felipe de Molina era chantre, "a tenido e tiene émulos y señaladamente lo an sido el doctor don Diego Felipe de Molina y un clérigo Thomé de Salinas por sus propias causas e intereses como parece por la información procurando 
dinigrar sus buenas obras" (Real Audiencia de La Plata 2007; X: 187) ${ }^{47}$.

Los conflictos que se dieron entre capitulares también se desarrollaron en la Audiencia. Francisco Márquez de Sotomayor, deán de la iglesia catedral, alertó de los intentos de un fiscal y un oidor de la audiencia "en procurar quitar la autoridad al presidente y al licenciado Lupidana, oidor más antiguo, personas xpristianas y de buen pecho, letras y experiençias, que en todas las ocasiones públicas y secretas lo hacían y hacen" 48 . El cuadro de relaciones se complicó, según el deán, con la llegada del oidor Gonzalo Calderón quien "se hiço consorte del Mora $\mathrm{y}$ fiscal de desanpararon el audiençia no acudiendo a ningún acto público de misa ni sermón ni otras partes con el audiençia" ${ }^{\prime 9}$. Para el deán estas parcialidades y bandos perjudicaban la administración de justicia por parte de la Audiencia. Un fenómeno similar afectó al cabildo eclesiástico.

Una rápida revisión de las actas del cabildo eclesiástico de La Plata permite matizar las críticas dirigidas por la audiencia respecto del supuesto mal gobierno del obispado. En sede vacante se nombró oportunamente provisor y vicario general, con las facultades arriba señaladas, para la administración del obispado. El deán y cabildo recibió las quejas contra visitadores, e incluso aprobó someter a juicio de residencia a estos para clarificar las acusaciones ${ }^{50}$. Esto aconteció en el caso de la visita encomendada al licenciado Michael de la Torre en 1587, contra quien hubo varias quejas que llevaron al cabildo a reemplazarlo, tras una detenida discusión, por el chantre Diego Felipe de Molina quien debió continuar la visita y proseguir con la correspondiente en $1588^{51}$. También se intentó ajustar las visitas a instrucciones que debían seguir los visitadores para evitar excesos. Sin embargo, estas instrucciones no fueron suficientes para prevenir abusos contra indios, curas y españoles, como fue el caso de la visita de 1589, comisionada al obispo de Paraguay, cuyas quejas condujeron a la derogación de la comisión por parte del deán y cabildo ${ }^{52}$. Es importante señalar que las disposiciones acerca de visitas del concilio provincial de 1583 solo se aplicaron en La Plata a partir de 1594 cuando fueron publicados en la diócesis por un acuerdo del cabildo eclesiástico, tras haberse aprobado en 1591 el texto normativo ${ }^{53}$. Hasta aquí los votos de los capitulares se habían fundamentado en el Concilio de Trento y en el segundo concilio limense, además de costumbres observadas en otras iglesias catedrales.
Más arriba se ha señalado los esfuerzos del deán y cabildo en ajustar a la clerecía a las normatividades del Concilio de Trento y del segundo concilio limense. Algunas de estas medidas también se aplicaron a los capitulares. Pareció ser un problema el cumplimiento de algunas obligaciones, por parte de aquellos, pues se iban "al tiempo de proueer justiçia y no vienen quando los llaman [a cabildo]"54. Los capitulares discutieron respecto del procedimiento adecuado para dirimir cuándo el capitular cometía falta. El chantre Diego Felipe de Molina sostuvo que todos los capitulares presentes en la ciudad debían concurrir al llamado de cabildo, aunque estuvieren ocupados en otros asuntos, sin embargo, la mayoría del capítulo consideró que un capitular podía solicitar licencia al cabildo para ausentarse y que el resto de los capitulares tenía la obligación de asistir al llamado a cabildo tal como lo propuso en aquella ocasión el chantre.

Varios de estos problemas no estaban contemplados en la constitución de erección redactada por el obispo fray Tomás de San Martín en 1553. El obispo murió antes de poder llegar a la sede episcopal. Los prelados posteriores no prestaron atención a la necesidad de adecuar estas constituciones. De ahí la importancia que adquiere el obispo Alonso Ramírez de Vergara en la organización del gobierno de la catedral y en el ordenamiento de la ciudad episcopal.

\section{Prestigio simbólico de la sede episcopal de La Plata}

La promoción de reliquias e imágenes milagrosas permitió al obispo Alonso Ramírez de Vergara reforzar el prestigio simbólico de la sede episcopal de La Plata. En esta perspectiva destaca el activo papel que jugó en la promoción del culto a la reliquia de la Santa Cruz de Carabuco y a la imagen de la Virgen de Guadalupe. Respecto de la reliquia de la Santa Cruz, el cronista jesuita anónimo señaló que "la inuención de esta cruz historia rara y aueriguada con particular inquisición del señor obispo de las Charcas don Alonso Ramires de Vergara, que se halló presente al hacerla" (Anónimo 1944: 292 [1600]). El cronista señaló que, con anterioridad al obispo, el cura doctrinero de Carabuco tuvo noticias del lugar en el que se encontraba enterrada la reliquia, la que procedió a trasladar a la iglesia, y conservó para sí dos clavos de bronce que se llevó cuando se fue de la doctrina. En la visita pastoral, el obispo 
hizo cavar nuevamente el lugar en el que estuvo enterrada la reliquia

"por decirle un indio muy uiejo del mismo pueblo, que la tradición que auía era, que la cruz tenía tres clauos, y que el vno se auía quebrado al hechar de la cruz en el hoyo [...] hallose el clauo, el qual lleuó su señoría a su iglesia cathedral; y en el camino dicen obró el Señor por medio dél la salud de vn camarero suyo de un graue dolor de estómago" (Anónimo 1944 [1600]: 296).

Al crearse el arzobispado de La Plata, en 1609, se trasladó una parte del madero a la iglesia metropolitana con el propósito de que la diócesis no se quedara sin tan preciada reliquia, porque la doctrina de Carabuco fue incorporada al obispado de La Paz. Hacia fines de la década de 1630, Pedro Ramírez del Águila, canónigo de la catedral de La Plata, consideró que el resto de la Santa Cruz depositado en la iglesia era "reliquia muy preciosa y santuario muy devoto y milagroso en toda esta tierra" (Ramírez del Águila 2017: 320 [1639]).

Asimismo, Alonso Ramírez de Vergara tuvo una activa participación en la promoción del culto a la Virgen de Guadalupe en La Plata. Se trata de una devoción ampliamente divulgada en la zona de Extremadura de la que era originario el prelado. Este culto no se inscribe en la tradición guadalupana novohispana, sino que en la tradición promovida por los monjes jerónimos extremeños. De hecho, en su periplo americano, fray Diego de Ocaña dotó con imágenes de la Virgen de Guadalupe al convento franciscano de Potosí y a la catedral de La Plata ${ }^{55}$. Diego de Ocaña insistió en que su trabajo no se redujo a realizar un mero retrato. De la imagen de Potosí sostuvo que se trataba de un verdadero original $^{56}$. En el caso de la imagen de La Plata, el fraile relató que hizo:

"la imagen como si yo fuera el pintor más extremado del mundo y puedo afirmar con verdad y en toda mi vida auía tomado pinzel alado con la mano para pintar sino fue en esta uez sin tener yo mas prática desto de la que tenía de la iluminación de aquellas ymágines que en España sin auer tenido maestro que me enseñare hacía y con la ayuda de Nuestra Señora fauoreciendo a mi buen deseo es de manera la pintura que no an tenido que enmendar famosos pintores que después vinieron" 57 .

Estas circunstancias reforzaron la calidad milagrosa de la imagen que el obispo puso bajo su control. Acá se debe señalar que fray Diego de Ocaña se alojó en casa del deán del cabildo "porque la imagen que se auía de hazer en esta ciudad la tomó a su cargo el deán y se auía de hazer en su casa", y fue él mismo quien encabezó la recolección de joyas para iluminar la imagen pintada por el fraile ${ }^{58}$. Esta indicación de Ocaña es reveladora del interés inicial que tuvo el cabildo en la promoción del culto a la Virgen de Guadalupe; además, de la tensión que pudo haber suscitado esta situación en la apropiación que hizo la sede episcopal. De hecho, la imagen fue instalada en una capilla en la que posteriormente se sepultaron los restos del obispo Alonso Ramírez de Vergara (Herrera 1996: 76 [1638]). En 1598, el obispo propuso al cabildo eclesiástico construir esta capilla para que sirviera "para sagrario de esta sancta iglesia y capilla de los curas de ella si atento a esto será bien dalle el suelo de la dicha lumbre para su entierro y edifiçio de la dicha capilla y que pueda poner en ella sus armas y poner que en ella no se entierre nadie si no su señoría en ella" ${ }^{59}$. El cabildo aprobó la propuesta considerando la falta de capillas en la iglesia catedral y que el obispo asumiría los costos de la construcción y mantención de la mencionada capilla. En la discusión, el canónigo Alarcón fue de parecer que la propiedad de esta capilla quedase para la iglesia catedral. Aunque los capitulares no se pronunciaron respecto de este punto, sin embargo, el cabildo tuvo a cargo los trabajos de ornamento de la capilla tras la muerte del obispo ${ }^{60}$.

Los milagros de la Virgen de Guadalupe se promovieron en sermones y en comedias que fueron representadas en la Villa Imperial de Potosí y en la ciudad de La Plata. Diego de Ocaña señaló que los sermones recogieron milagros difundidos en un libro de Gabriel de Talavera que debió ser Historia de Nuestra Señora de Guadalupe publicado en 1597. Estos sermones estimularon la devoción a la imagen, lo que se acrecentó con la rápida divulgación de milagros acaecidos en Potosí y en La Plata durante la estadía del fraile jerónimo. Hacia 1638, Antonio de Herrera, racionero de la catedral de La Plata, señaló que esta

"santa imagen es en toda esta comerca [comarca] muy venerada y tenida por 
milagrosa, aunque a vueltas de esta devoción (por su mucha riqueza) se le atreven algunas veces y le hurtan joyas de mucho valor, no obstante que su Capilla está siempre cerrada y la imagen, cubierta con tres velos de seda y oro también cerrados en los lados con remate con candados" (Herrera (1996 [1638]: 77-78).

En los momentos en que se originaba el culto a la Virgen de Guadalupe, el cabildo eclesiástico promovió la instalación de otro culto mariano. Para esto se aprovechó las repercusiones que tuvo el terremoto de 10 de noviembre de 1601. Ese sábado en la mañana, una gran multitud de fieles concurrió a la iglesia a participar en una misa en honor a la virgen, estando en esta "vuo vn gran terremoto y temblor en que se conoçió claramente que nuestro Señor auía vsado de misericordia porque estuuo esta santa iglesia a punto de caerse de que suçedieran muchas muertes" 61 . En la misma celebración se encontró fray Diego de Ocaña, quien estaba en el coro de la catedral junto al deán, quien registró que "vino tan grande temblor de tierra en toda la ciudad y su comarca que pareçió ser la fin del mundo, porque la iglesia es de bóveda, y comenzó a despedir de sí algunos pedazos y las paredes de la mesma suerte" 62 . Aunque el temblor "duró muy poco no más de quanto pudo durar un avemaría", sin embargo, provocó fuertes daños en casas, iglesias y conventos. De acuerdo con fray Diego de Ocaña, el temor que provocó el terremoto provocó que "la gente atemorizada tuviese alguna deuoción con nuestra Señora, y así toda la ciudad vn boto de çelebralle vna fiesta"63.

Por otra parte, en el acta del cabildo, anteriormente citada, se señala que fue este quien propuso, a la audiencia y al obispo, la realización anual de una fiesta a la Virgen en reconocimiento al beneficio obrado en favor de la iglesia y la feligresía. En el acta se consignó que esta celebración se realizaría "en la fiesta de nuestra Señora el día de la presentación", es decir, el 21 de noviembre. Esta fiesta no se encuentra señalada entre las fiestas de preceptos establecidas por el concilio provincial de 1583 (Vargas 1951; I: 366), porque Pío V la suprimió del Breviario, pero fue reincorporada por Sixto V en 1585 (Abad y Garrido 1997: 824; Bergier 1846: 783; Lobera y Avio 1846: 473). Según García, en esta fiesta se advocó a la Virgen del Temblor (García 1999: 21). En las relaciones de la iglesia catedral de La Plata, escritas a mediados del siglo XVII, no hay ninguna mención a esta imagen (Herrera 1996 [1638]; Ramírez del Águila 2015 [1639]). En el siglo XVIII, la fiesta de la Presentación de Nuestra Señora continuó realizándose sin que se asocie a ninguna advocación (Castañeda y Hernández 2007: 440).

\section{Constituciones, estatutos y regla consueta}

A inicios de la década de 1590 , el presidente de la audiencia de Charcas informó que llegó una cédula real, fechada en abril de 1588 , respecto que los curas no interviniesen en los testamentos de los indios. Junto con otros aspectos, el presidente señaló que en "llegando el nuevo obispo a su Iglesia, la comunicaré con él y diré haga sínodo, o consulta, en que mándese cumpla sin replica lo que vuestra magestad manda" ${ }^{64}$. Este sínodo no se realizó y tampoco llegó el prelado esperado. Algunos autores sostienen que el obispo Alonso Ramírez de Vergara realizó un sínodo en 1597 que se plasmaron en unas constituciones (Dussel 1979, 1983; García 1964; Martínez de Sánchez 2013). Esta confusión pudo surgir del texto del segundo sínodo diocesano de La Plata celebrado en 1627.

En las constituciones de ese sínodo, el arzobispo Fernando Arias de Ugarte señaló que los prelados Alonso Ramírez de Vergara, Alonso de Peralta y Jerónimo Méndez de Tiedra redactaron constituciones, respectivamente (Arias de Ugarte 1629: 3). Solo en el caso del arzobispo Jerónimo Méndez de Tiedra, Fernando Arias de Ugarte indicó que las constituciones se redactaron en el marco de un sínodo (1619-1620), es decir, de una congregación del obispo con el clero de la diócesis charqueña. El arzobispo conoció bastante bien las constituciones del obispo Alonso Ramírez, así como las circunstancias de su producción, pues llegó a la audiencia de La Plata al año siguiente de la redacción de aquellas ${ }^{65}$; más aún él remarcó que "siempre las emos tenido en nuestro poder, en las Audiencias, è Iglesias, que emos seruido" (Arias de Ugarte 1629: 3). Fernando Arias de Ugarte no vinculó estas constituciones con un sínodo diocesano, como sí lo hizo en el caso de las constituciones de Jerónimo Méndez de Tiedra, las que más apropiadamente deben designarse como constituciones sinodales. Estas fueron confirmadas en el sínodo de 1627, con excepción de aquellas disposiciones que fueron revocadas (Arias Ugarte 1629: $17 \mathrm{v})$. 
Las constituciones sinodales y las constituciones de Alonso Ramírez de Vergara abordaron materias bien diferenciadas. Pedro Ramírez del Águila, quien fue secretario del mencionado prelado, señaló que el "señor obispo don Alonso Ramírez de Vergara, hizo constituciones para el gobierno de esta santa iglesia y coro, que se guardan" (Ramírez del Águila 2015: 340). Antonio de Herrera, compañero de Ramírez de Águila en el cabildo de La Plata, señaló que el obispo "hizo las Constituciones con que hoy se gobierna esta Santa Iglesia, que por ser tales tan conformes a la veneración del cultivo divino, autoridad y observancia del Coro, todos los señores Arzobispos sus sucesores las han aprobado y confirmado" (Herrera 1996: 101 [1639]). En este sentido, las constituciones sinodales impactaron en el conjunto de la diócesis, a diferencia de las constituciones de 1597 que se vinculaban al culto y gobierno en la iglesia catedral y en la ciudad episcopal. Las constituciones de Alonso Ramírez de Vergara tuvieron una larga vigencia en la iglesia catedral de La Plata.

Ahora bien, la relación de estas constituciones con un sínodo no resulta antojadiza. Este cuerpo jurídico era materia de sínodos diocesanos o concilios provinciales (Martínez de Sánchez 2008; Terráneo 2011). Precisamente, las constituciones de 1597 fueron reemplazadas por una Regla Consueta redactada en 1778 por los prelados que asistieron al II Concilio provincial de La Plata ${ }^{66}$. Pero este no fue el caso de las constituciones de 1597. Estas se generaron en el marco de una visita pastoral y no en el de una asamblea sinodal como solía suceder. El propio obispo Alonso Ramírez de Vergara señaló que:

"estando actualmente entendiendo en la dicha visita, con deseo que en nuestra santa iglesia aia el gouierno, concierto, cuidado y puliçía y las demás cosas conuenientes y necesarias para el buen seruiçio del culto diuino, y administración de los bienes y rentas, así de la fábrica de ella, como de las demás perteneçientes a nos, y los dichos Deán y Cauildo"67.

A ojos del obispo, la visita confirmó la necesidad de reglar varios aspectos del gobierno de la iglesia, así como los referidos al culto divino, la administración financiera, entre otros, que eran de obligación del prelado y del deán y cabildo, y que no estaban delimitados en el documento de erección de la iglesia, ni menos aún fueron objeto de normatividad por parte de los posteriores prelados de La Plata. A partir de esto, Alonso Ramírez de Vergara determinó la elaboración de constituciones y estatutos de la iglesia catedral apoyado en la facultad otorgada por el Concilio de Trento "y por la que la ereçión nos da y conçede para reformar lo que conuenga, y poner, y quitar, y declarar, y mandar guardar en ella las çeremonias, usos, y buenas costumbres, que conuengan y se guardan en las yglesias catedrales de estos reinos de los de Castilla" ${ }^{68}$. En esto último es posible observar una declaración común en las iglesias catedrales americanas, pues, entre otros aspectos, en la erecciones se estableció "celebrar los divinos ofícios al modo que se celebraban en la Santa Iglesia Sevilla" (Solórzano 1648: 520). Leticia Pérez (2016b) ha sostenido que el funcionamiento de las iglesias catedrales en las Indias distó bastante de lo planteado en las erecciones. Además, por sus ingresos difícilmente pudieron alcanzar el esplendor de la iglesia catedral sevillana.

En el procedimiento del obispo se observa una diferencia respecto del utilizado, en 1593, por el arzobispo Toribio de Mogrovejo en la redacción de las ordenanzas de la iglesia catedral de Lima. Esta fue acordada en una sesión del cabildo en la que "se trató sobre el hacer la Consueta para el servicio de la dicha santa Iglesia y habiéndolo tratado y comunicado que se hiciese y para el dicho efecto por su Señoría se nombró al licenciado Bartolomé Menacho, canónigo y por el dicho Deán y Cabildo se nombró al doctor Antonio de Molina canónigo" (Grignani 2019: 183). De hecho, este procedimiento se encuentra debidamente respaldado en las disposiciones del Concilio de Trento (Oviedo 1986: 130; Grignani 2019: 105). En el caso de Alonso Ramírez de Vergara, este convocó a cabildo el 31 de marzo de 1597:

\footnotetext{
"después de hauer propuesto el obispo mi señor lo contenido en las dichas constituciones y el celo con que las hauía hecho y hordenado mandó que se leyesen y notificasen y las ley e notifiqué en el dicho cauildo de manera que todos lo oyeron y a cada uno por lo que [tachado. se] les toca se lo notifiqué y todos los dichos señor Deán y Cauildo unánimes y conformes y de por sí como ban declarados dixeron que lo oyan" 69 .
}

La denominación de constituciones y estatutos se impuso por sobre la de regla consueta. Estas 
remiten a instrumentos jurídicos bien delimitados en el derecho canónico. En el caso de la constitución eclesiástica, se refiere a disposiciones en las que se distinguen tres tipos: las disposiciones de concilios, los decretos papales y episcopales, y las sentencias de los padres de la iglesia (André, Romo y Pastora 1847, II: 105). En este sentido, la expresión constituciones se utiliza por cuanto se trata de disposiciones emanadas de la autoridad episcopal. Por su parte, los estatutos correspondían a cánones de disciplina eclesiástica de los que se distinguían tres clases: los de las órdenes religiosas, los de los obispos y los de los cabildos (André, Romo y Pastora 1847, II: 300).

También el documento de 1597 fue rotulado como "Ejecutorial del obispado de Los Charcas". ¿Qué uso tuvo la ejecutorial en el ámbito eclesiástico? Esto da una pista para entender el procedimiento que utilizó Alonso Ramírez de Vergara en la elaboración de las constituciones y regla consueta de la iglesia catedral. De acuerdo con el Diccionario de Autoridades, la designación de ejecutorial se "aplica a los despachos o letras que comprenden la ejecutoria de alguna sentencia de un tribunal eclesiástico" (RAE 1814: 342,1). La ejecutoria es el despacho de una sentencia que no admite apelación y que se considera cosa juzgada. Esto último es bastante indicativo del procedimiento que utilizó el obispo Alonso Ramírez de Peralta para dictaminar las constituciones y estatutos de la iglesia catedral, cuya elaboración juzgó facultad privativa de su cargo.

Ahora bien, el documento de La Plata no recibió la denominación de consueta, como fue el caso en la catedral limeña, tal vez porque el interés del obispo fue reafirmar el control episcopal sobre el cabildo catedralicio. No obstante, el documento trata asuntos propios de una regla consueta. De hecho, un traslado firmado en 1787 por Pedro de Cabrera Urriola, notario público de La Plata, y realizado por mandato del gobernador del arzobispado, fue rotulado "Erección, constituciones y regla consueta de esta iglesia catedral metropolitana de La Plata"70. Como se ha mencionado más arriba, para ese entonces estaba en uso la Regla Consueta de 1778 en las iglesias catedrales del arzobispado. De acuerdo con Oviedo, las reglas consuetas "contenían un ordenamiento de los oficios y obligaciones de los canónigos, del culto de la catedral y de la vida del clero de la ciudad episcopal. Es decir, eran un ordenamiento pastoral de la vida de la Iglesia en torno a su catedral" (Oviedo 1986: 133). La voz latina consueta (de consuesco "acostumbrarse, habituarse a") se tradujo al castellano como "consuetudinario, habitual, acostumbrado, ordinario", por lo demás, consuetudinario es una voz que se introdujo en español en el siglo XVI (Segura 2006: 161). Ahora bien, este ordenamiento incorporó ciertas prácticas acostumbradas (consuetas), o costumbres, vigentes en las iglesias catedrales de Castilla y en la metropolitana de Lima.

Las constituciones del obispo se ordenaron en 41 capítulos. En los capítulos $1^{\circ}$ al $6^{\circ}$ se reguló las funciones de dignidades (deán, arcediano, chantre, tesorero y maestreescuela), canonicatos y porcionarios o racioneros. En su conjunto, estos conformaron el cabildo o capítulo catedralicio cuya prebenda y emolumentos dependía de la mesa capitular, es decir, de los bienes derivados de donaciones reales y de los diezmos o bienes decimales (Martínez 1998: 42). De ahí entonces que la expresión "comemos de una mesa todos", que se analizará más abajo, no es solo una metáfora. Las rentas del cabildo se distribuyeron según la calidad de la prebenda.

En estos capítulos se amplió o precisó los oficios de algunas dignidades, además de especificar nuevos cargos dependientes de estas. En el caso del deán, se reforzó la autoridad en el gobierno del coro, en la convocatoria y regulación del cabildo, así como en el castigo a las faltas de los capitulares. Sin embargo, se remarcó que estas funciones corresponden "al deán no estando presente el prelado, porque estando en el choro, cabildo, o proçesiones, a él se deue la presidencia, correction, y gouierno"71. En el caso de la cantoría o chantría, se introdujo el sochantre que suplía algunos oficios propios del chantre. Para costear este cargo, el chantre contribuía con algo de su prebenda y el cabildo con otro tanto. Al tesorero también se amplió las funciones a su cargo. Entre otros aspectos, se le ordenó tener en custodia los ornamentos de la iglesia (oro, plata y tapicería), haciéndose responsable de estos. Asimismo, para el cumplimiento de estas obligaciones debía designar a un sacristán. Paro evitar cualquier inconveniente en el incumplimiento de estas obligaciones se agregaron dos modalidades de control. Por una parte, el tesorero se obligaba al pago (fianza) de las posibles pérdidas ocasionadas en la gestión del sacristán. Por otra, tesorero y sacristán debían dar cuenta a dos capitulares del inventario de los bienes de la iglesia catedral. 
Al maestreescuela le fue encargado leer casos de conciencia, en vez de Gramática porque ya se enseñaba en el Seminario, para una mejor formación de los sacerdotes. Estos fueron obligados no solo a asistir, sino que debían obtener la licencia del maestreescuela para ordenarse. Además, se encargó a esta dignidad supervisar el trabajo del catedrático de Gramática del Seminario, revisando los libros que ocupaba y la asistencia de los seminaristas.

Un conjunto de capítulos reguló la celebración del culto divino (capítulos $9^{\circ}$ al $11^{\circ}$ ), las horas litúrgicas (cap. $12^{\circ}$ ) y el comportamiento en el coro (capítulos $13^{\circ}$ y $14^{\circ}$ ). La liturgia diaria constituyó el núcleo del quehacer de los capitulares. De acuerdo con esto, recogiendo lo establecido en las catedrales castellanas, se estableció que quienes realizaban misas recibieran una retribución aparte de la prebenda que les correspondía. La celebración de estas debía estar debidamente anotada, del mismo modo que las inasistencias y retrasos en la llegada al coro y altar. Un mecanismo de recompensas y multas pecuniarias se introdujo para constreñir a los capitulares al cumplimiento de sus obligaciones. Además, se enfatizó la necesidad que los prebendados se comportasen con decencia y compostura en el coro, debiendo permanecer en la silla y en el coro que le correspondía. Esta etiqueta era fundamental para realzar la dignidad de los capitulares, particularmente en la misa. En esta se precisó que se debía mantener el orden de levantarse y sentarse según lo establecía el Misal, además de lo que prescribiese el maestro de ceremonias. En este sentido, la etiqueta del ceremonial ordenaba el comportamiento del capítulo catedralicio para que ninguno se comportase según su parecer, sino que con obediencia y orden.

Los capítulos $15^{\circ}$ al $21^{\circ}$ profundizan la necesidad de regular el comportamiento de los prebendados, incluso en el período en que estaban autorizados a descansar (recle) que correspondía a dos meses. El recle no podía ser solicitado entre el Domingo de Ramos (Dominica Palma) hasta el Domingo de Resurrección porque en estos días los capitulares debían estar obligatoriamente presentes. Además, se agregó el período de otras celebraciones. Si el capitular asistía a la misa estando de recle debía vestirse apropiadamente acorde con su dignidad, es decir, con hábito de coro (capa o sobrepelliz). Además de los dos meses de recle, los capitulares podían tomarse mediodía, cada veinte días, para hacerse la barba, una cuestión que no era menor considerando, p. e., que aquella podía dificultarle beber el cáliz.

Para remarcar el distanciamiento con el hombre mundano, el hábito del capitular debía ser decente, sin colores ni alamares, y tampoco podían ir con ropa de levantar a la iglesia. En su comportamiento los capitulares debían dar olor -es decir, fama o reputación- y ejemplo de manera que no fueran menos valorados por los feligreses. Por lo que se insistió en que no debían concurrir a tiendas, tabernas y carnicerías en consideración a la dignidad de su oficio. Un aspecto que contrasta con su activa participación en el mundo como lo demuestra una rápida revisión de las escrituras públicas.

A la diferenciación con el resto de la clerecía y de la feligresía, las constituciones agregaron la necesidad de armonizar las relaciones entre los capitulares bajo el supuesto que eran "sieruos de un Señor y comemos de una mesa todos". Hermandad, unión y respeto debían mediar los tratos entre los prebendados, además de reconocer la jerarquía correspondiente a la dignidad y a la antigüedad. En este mismo sentido, se insistió en la necesidad de armonizar las relaciones entre los capitulares, prohibiéndose el uso de apodos o de burlas, además que se profiriesen entre sí palabras injuriosas o escandalosas en el coro. En caso que estas faltas se concretasen, las constituciones alentaban la rápida sanción de las mismas. Aunque las sanciones fuesen impuestas por el deán y cabildo, sin embargo, se insistía en que no por esto cesaba el castigo que podría imponer el prelado. Para esto se argumentó que varias faltas quedaban bajo la jurisdicción del ordinario.

Junto con la liturgia, los capitulares debían atender varios asuntos respecto de la administración de la iglesia catedral y de la sede vacante. De ahí que se insistiera en la modalidad del cabildo y sus propósitos (capítulos $22^{\circ}$ al $24^{\circ}$ ), distinguiéndose entre cabildo general y ordinario. En el primero, que debía realizarse el primer viernes de cada mes, tenía por propósito tratar asuntos de "reformación y corrección" respecto de la celebración del culto y del cumplimiento adecuado de los oficios, por lo que a este cabildo debían asistir los capitulares y demás oficiales de la iglesia catedral. En el cabildo ordinario, que se debía realizar los días martes de cada semana, se trataban los asuntos de hacienda y administración de la iglesia catedral y de la sede vacante cuando correspondía. Además, se estableció 
una etiqueta en la votación de acuerdos o resultas, según este, se debía respetar las jerarquías y la antigüedad de los capitulares, y no estaba permitido replicar la votación de otro. Con anterioridad, esto suscitó desencuentro en el cabildo de La Plata. Para votar en asuntos que afectaban a capitulares se estipuló el voto secreto para evitar contrariedades y confrontaciones. Las dignidades y canónigos podían votar en todos los asuntos, sin embargo, los racioneros solo podían votar en asuntos de hacienda y administración.

En los capítulos $25^{\circ}$ al $28^{\circ}$ se regulan aspectos concernientes a la media anata para los prebendados difuntos, residencia, juramento y jubilación. Lo referido a la media anata fue uno de los pocos capítulos en que se precisó del consentimiento del deán y cabildo porque afectaba directamente la distribución de los bienes decimales. Los prebendados difuntos podían recibir la mitad de los frutos correspondiente a la prebenda de un año. Esto porque alguno podría fallecer sin tener los recursos necesarios para costear los gastos de las exequias y misas. Otro capítulo en que se precisó del consentimiento del deán y cabildo fue en el correspondiente a la jubilación para aquellos prebendados que hubiesen servido cuarenta años en la iglesia catedral (cap. $28^{\circ}$ ). En el caso de los nuevos prebendados, estaban obligados a residir durante seis meses continuos para que aprendiesen el funcionamiento (o las costumbres) de la iglesia catedral. Asimismo, debían hacer juramento de guardar los estatutos de la iglesia catedral, obediencia al prelado, respeto a capitulares, asegurar el bien público de la iglesia temporal y espiritual y confidencialidad en las tareas encargadas por el obispo o el cabildo.

En los capítulos $30^{\circ}$ al $38^{\circ}$ se delimitaron las funciones propias de diversos oficios: maestro de capilla, maestro del seminario, apuntador, colector, mayordomo de fábrica, mayordomo de cabildo, hacedores de rentas y contadores. Estos oficios se elegían después de año nuevo, pero hubo algunos que podían ser ejercidos por capitulares. La elección de estos últimos se hacía por voto secreto, estando obligado a aceptar la elección bajo la consideración que cada prebendado debía aportar con sus talentos al servicio de la catedral.

En los dos últimos capítulos se definió la obligación que tenían los curas y clérigos de la ciudad en la participación de algunas ceremonias celebradas en la iglesia matriz (cap. 40) y la obligación de la lectura anual de las constituciones, así como las copias que debía haber de estas $\left(\right.$ Cap. $41^{\circ}$ ).

Ahora bien, las consideraciones establecidas en estas Constituciones pueden conducir a pensar que el deán y cabildo no atendió con prolijidad el culto y la administración de la iglesia catedral. De hecho, los capitulares se guiaron por la erección de 1553, las disposiciones del Concilio de Trento o de los concilios limenses, así como por las costumbres usadas en otras iglesias catedrales. García Quintanilla (1964) sostuvo correctamente que varios aspectos incorporados en las Constituciones del obispo Alonso Ramírez de Vergara se encuentran en los acuerdos alcanzados por el cabildo eclesiástico en años anteriores. Lo peculiar de las Constituciones de 1597 fue precisamente que homogeneizaron las prácticas y las ajustaron a un cuerpo normativo que intentó subordinar al cabildo a la jurisdicción episcopal.

\section{Jueces consiliarios y distribución de diezmos}

En el cabildo catedralicio hubo una tendencia a colocar contrapesos a la jurisdicción episcopal. En 1587, los miembros del cabildo señalaron que el Concilio de Trento, y un nombramiento realizado en 1568 , les permitía elegir jueces consiliarios "para que con el Ilustrísimo de este obispado se hallen en los negoçios que tocaren a los señores capitulares çibiles y criminales"72. En 1568, el arcediano Francisco Palacios de Alvarado, provisor del obispado, abrió un proceso contra los canónigos Cosme de Perea y Alonso de Arceo "sobre ciertas palabras y desacatos que contra él dixeron sobre rraçón de aver mandado los dichos canónigos hechasen al cura y su rropa de unas casas que están junto a la iglesia" (Audiencia de La Plata 2007; I: 463 [31VIII-1568]). El enfrentamiento entre el arcediano y los canónigos se había recrudecido con anterioridad a este suceso. Por comisión del obispo Domingo de Santo Tomás, el arcediano procedió "contra los del Cavildo que fueron en elegir jueces para que juntamente conociesen con el dicho señor Obispo contra los prebendados de la yglesia" (Audiencia de La Plata 2007; I: 464 [31-VIII-1568]). El oidor Antonio López de Haro señaló que la discordia no involucraba solo a los dos canónigos, sino que la mayor parte del capítulo catedralicio. A juicio del oidor, los canónigos debían desistir de la elección; además, planteó que el provisor no tenía jurisdicción sobre la expulsión del cura porque se trataba 
de una materia administrativa que era facultad del cabildo. Por su parte, el oidor Juan de Matienzo fue de parecer que la Audiencia no debía actuar como juez árbitro en la disputa entre el provisor y los canónigos, señalando

"que aunque la administración sea del Cavildo pero que el juez pudo mandar lo le pareció cerca de ello y que si ellos apelaran y se quexaran en esta Audiencia se tratará de ello pero que por su autoridad no pudiera rresistir ni enjuiciar al Provisor" (Audiencia de La Plata 2007; I: 464 [31-VIII-1568]).

En el caso de los jueces nombrados por el cabildo, el oidor Juan de Matienzo consideró que no era una materia en la que se hubiese pedido un pronunciamiento a la Audiencia.

Ahora bien, este conflicto evidencia la convicción predominante en el capítulo catedralicio respecto de su lugar en el gobierno de la diócesis. Recientemente el Concilio de Trento había reforzado la jurisdicción episcopal, con pérdida de la autonomía corporativa que gozaban los cabildos catedralicios. No es de extrañar que los canónigos charqueños hubieran asumido esa identificación corporativa, que, de acuerdo con Drapper (2000), se reforzó en la primera mitad del siglo XVII. Incluso esto los condujo a enfrentarse con los oficiales de la Audiencia. El canónigo Alonso de Arceo tuvo enfrentamientos en diversos niveles. En su calidad de provisor del obispado, en 1575 removió curas doctrineros nombrados por el virrey Francisco de Toledo apoyado en la interpretación de una cédula real $^{73}$. Ante la solicitud de amparo de un clérigo removido, el provisor presentó una petición

"que el señor Presidente la rremitió al Acuerdo y salidos de Audiençia dixo algunas palabras desacatas, y Su Señoría, como lo tiene por loco, disimuló con él y entró en su aposento" (Real Audiencia de La Plata 2007; II: 531 [11-VIII-1575]).

El oidor Manuel Barros fue de parecer que "se dé noticia a la sede vacante para que castiguen a aquel clérigo" (Real Audiencia de La Plata 2007; II: 531 [11-VIII-1575]). Estos conflictos son expresión del policentrismo jurisdiccional común a las instituciones del Antiguo Régimen, incluidas las instituciones eclesiásticas, así como el ejercicio efectivo que se hizo de las jurisdicciones (Barriera 2006). Más allá de la personalidad excéntrica del canónigo Alonso de Arceo, no puede desconocerse que su práctica evidencia ese hacer jurisdicción, para retomar a Barriera.

En otras diócesis la designación de jueces consiliarios o adjuntos también provocó enfrentamientos entre el prelado y el capítulo catedralicio (Coello de la Rosa 2011; Solórzano 1648; Terráneo 2018). Como se señaló arriba, en 1587 el deán y cabildo charqueño retomó la elección anual de jueces consiliarios, sin que hubiera inconvenientes con el obispo Alonso de la Cerda (1587-1592). Sin embargo, en 1598 se debió enfrentar ciertos inconvenientes con el obispo Alonso Ramírez de Vergara respecto de la elección de jueces consiliarios y de la preeminencia de los prebendados.

Jueces consiliarios obispado de La Plata, 1587-1602

\begin{aligned} & \hline Año \multicolumn{1}{c}{ Jueces consiliarios } \\ & \hline 1587 $\begin{array}{l}\text { Tesorero Francisco Vásquez y maestreescuela Juan } \\ \text { de Larrategui. }\end{array} \\ & 1590 \begin{array}{l}\text { Deán y canónigo Bartolomé Perea. } \\ 1591\end{array} \\ & 1592$ Chantre Diego Felipe de Molina y canónigo Tomás López \\ & 1594 $\begin{array}{l}\text { Tesorero Francisco Vásquez y canónigo Pedro Bravo. } \\ \text { Almeyda }\end{array} \\ & 1595$ Juan de Larreategui y canónigo Bartolomé de Perea \\ & 1597 $\begin{array}{l}\text { Maestreescuela Juan Sáenz y canónigo Bartolomé } \\ \text { de Perea }\end{array} \\ & 1598 \begin{array}{l}\text { Tesorero Francisco Vásquez y canónigo Diego Granero } \\ \text { de Alarcón }\end{array} \\ & 1599$ Canónigos Domingo de Almeyda y Juan de Mendoza \\ & 1601 Canónigos Diego Granero de Alarcón y Diego de Trejo \\ & 1602 Arcediano Gonzalo de Alarcón y tesorero Francisco \\ & Vázquez \\ & \hline\end{aligned}

Fuente: ABAS, AC, Actas Capitulares, vol. 1.

Entre los capitulares primó la convicción de que la elección de jueces consiliarios les otorgaba atribuciones judiciales, además, esto podía entenderse como una limitación de la propia actuación de los obispos (Rico 2019: 235). De ahí que algunos prelados consideraran que los jueces adjuntos eran asesores sin ninguna atribución judicial. Aspecto que estaba en concordancia con las disposiciones del Concilio de Trento en el que se insistió que los cabildos de las catedrales no podían alegar ninguna costumbre o sentencia para oponerse a los prelados (Ses. VI, Dec. sobre la reforma, cap. IV, Concilio de Trento 1848: 88). De acuerdo con Donoso, con 
anterioridad a esta disposición "los Cabildos de varias iglesias catedrales gozaban, por privilegio ó costumbre inmemorial, una completa exención de la jurisdicción del obispo en causas criminales" (Donoso 1858; I: 388). Sin embargo, el Concilio estableció que, en las iglesias catedrales en las que hasta entonces se había practicado, el cabildo debía elegir anualmente "dos de sus capitulares, con cuyo parecer [consilio] y asenso [assensu] esté obligado á proceder el Obispo, o su vicario, tanto en la formación del proceso, como en todos los demás actos, hasta finalizar inclusivamente la causa" (Ses. XXV, cap. V, Dec. sobre la reforma, Concilio de Trento 1848: 394). En esta disposición el cabildo de La Plata encontró apoyo para la designación de jueces consiliarios. A estos se les reconoció la facultad de dar su parecer en una deliberación, de ahí el uso de la expresión culta consiliario (del latín consiliarius, "relativo al que delibera o da consejos" [Segura 2006: 158]) en las actas capitulares de La Plata, pero, además, en el resultado de la deliberación estos jueces también daban su asenso (del latín assensus), es decir, su asentimiento, aprobación o consentimiento. Por lo que el parecer y asenso de los jueces podía contrariar el del propio prelado. Según Juan de Solórzano, estos jueces se introdujeron "para moderar la dureza, violencia, ò tirania de algunos Prelados" (Solórzano 1648: 620). Además, advirtió de la férrea oposición de algunos prelados, en la primera mitad del siglo XVII, a la designación de estos jueces pretextando que esta disposición no regía para las catedrales de las Indias porque la mayoría se crearon después del Concilio de Trento. Además de esto, los obispos señalaban que a las comunes diferencias entre los capitulares se agregaba otra al nombrarlos "sus conjudices, sin grave dimunicion de lo Episcopal (Solórzano 1648: 621).

El rechazo a los jueces adjuntos o consiliarios fue también objeto de discusión en la obra del prelado Gaspar de Villarroel quien reconoció que se trataba de una materia largamente debatida, al mismo tiempo que expresó que era dichoso "el Prelado, ;en cuya Audiencia sobre esta disputa! yo en tanto aborrezco los adjuntos, en quanto me mataron pleytos" (Villarroel 1738; I; 570). Sin lugar a dudas, el obispo Alonso Ramírez de Vergara pudo haber compartido este juicio. En la iglesia metropolitana el propio arzobispo había tenido problemas con el nombramiento de jueces consiliarios. Lo mismo se advirtió en otras diócesis del arzobispado, como fue el caso de Quito en el que se nombraban jueces adjuntos "de tiempo ynmemorial a esta parte [1630] se han nombrado en los cauildos que se hazen a los principios del año"74, sin embargo, esta nominación tuvo serios reparos en diversos prelados. En otras diócesis, la elección de jueces adjuntos contó con el acuerdo del cabildo con el obispo, como fue el caso del obispado de Tucumán (Terráneo 2018: 171).

La regla consueta de Alonso Ramírez abrió también un conflicto con el deán y cabildo respecto de la distribución de la renta decimal. A más de un mes de haberlas comunicado al capítulo catedralicio, se realizó un cabildo en el que se trató acerca del arriendo de los diezmos y el nombramiento de un mayordomo ${ }^{75}$. El deán propuso el nombramiento del mayordomo de la fábrica para que cumpliese con esta labor, sin embargo, la mayoría de los capitulares, con excepción del tesorero, fue de parecer que este asunto debía ser tratado con el obispo. Incluso el canónigo Antonio Bautista observó que la propuesta del deán era contraria a las Constituciones publicadas por Alonso Ramírez de Vergara en las que se estableció que la administración de los diezmos quedaba a cargo de dos personas, una nombrada por el cabildo y otra por el obispo. Las dos dignidades del capítulo catedralicio mantuvieron la noción que la distribución de las rentas decimales era una tarea propia del capítulo. Hasta el momento el avance de la investigación no ha permitido explorar el desarrollo de este desacuerdo. Al parecer posteriormente no hubo mayores dificultades en el procedimiento de designación de administradores del diezmo según lo estipulado en las Constituciones de 1597. Donde sí hubo dificultades fue en la división de los diezmos. Hacia 1600, los capitulares insistieron que dicha distribución se hiciera según la erección de las catedrales de Lima y del Cuzco, "por quanto sus mercedes eran defraudados en mucha cantidad de pesos por no hazerse según y de la manera que en las dichas yglesias se haze"76.

\section{Observaciones finales}

A fines del siglo XVI, la diócesis charqueña fue impactada por una estrategia de prestigio simbólico y control episcopal desplegada por el obispo Alonso Ramírez de Vergara. Aunque esta estrategia no se puede aislar del impacto de las orientaciones regias acerca del gobierno espiritual, sin embargo, no debe descuidarse que el prelado se enfrentó a 
un cuerpo fuertemente asentado tras largos período de sede vacante. En esta perspectiva, esta estrategia trató de aminorar la preponderancia del capítulo catedralicio y de recuperar el predominio en la ciudad episcopal de La Plata.

Precisamente la sede vacante permitió al deán y cabildo platense ganar preponderancia en la ciudad episcopal y en el conjunto de la diócesis. Sin embargo, la constitución del capítulo catedralicio fue lenta. Solo a inicios de la década de 1590 se amplió el número de capitulares: se pasó de cuatro a ocho canónigos y se incorporaron por primera vez tres racioneros. Varios de sus miembros permanecieron por largos períodos lo que dio continuidad al gobierno de la catedral, pero también hizo prolongar los conflictos entre los capitulares. Esto se tradujo en bandos y parcialidades que denunciaron los miembros de la audiencia. Precisamente, las Constituciones de 1597 intentaron superar esas dinámicas mediante la imposición de procedimientos de votación que evitaran la confrontación entre los capitulares. Sin embargo, las relaciones y desavenencias entre capitulares tenían una profundidad mayor que difícilmente podían ser eliminadas.

Ahora bien, en el procedimiento de elaboración $\mathrm{y}$ en los instrumentos jurídicos utilizados para la elaboración de las Constituciones de 1597 se expresa de manera más adecuada la estrategia de subordinación del capítulo catedralicio al obispo. En primer lugar, estas fueron elaboradas tras la realización de una visita pastoral y no en el marco de un sínodo diocesano. La redacción fue realizada enteramente por el obispo, con excepción de dos capítulos en los que se requería del consentimiento del deán y cabildo. Los instrumentos jurídicos fueron constituciones, estatutos y ejecutorial, es decir, aquellos en los que se expresaba las facultades de la jurisdicción ordinaria o episcopal.

\section{Agradecimientos}

En el Archivo y Biblioteca Arquidiocesanos de Sucre Avelina Cepeda Spada, directora, y Elizabeth Paniagua, secretaria, me han brindado, a pesar de las circunstancias, las mejores condiciones para realizar diversas estadías de investigación en los últimos años. En el Archivo y Biblioteca Nacionales de Bolivia, la archivera Nelva Delgadillo brindó una esmerada y prolija orientación archivística y respondió con profesionalismo nuestras consultas. A los evaluadores anónimos del manuscrito por sus críticas, comentarios y sugerencias. El Dr. Jorge Hidalgo y la Dra. Macarena Cordero realizaron observaciones y recomendaciones bibliográficas, así como también los miembros del Seminario de Idolatrías e Instituciones Eclesiásticas (IIH-UNAM) dirigido por el Dr. Gerardo Lara. Dedico este trabajo a la memoria del Ing. Efraín Álvarez Almendras (1958-2020) de quien aprendí, junto con el cariño de su familia, de Chuquisaca, su tierra, su pueblo y su historia; además, en su casa de Sucre escribí un primer borrador de este trabajo, en febrero de 2020, que concluí en Valparaíso tras la noticia de su irreparable pérdida.

\section{Referencias Citadas}

Abad, J. y Garrido, M.

1997 Iniciación a la liturgia de la iglesia, Madrid, Ediciones Palabra.

Acosta, A.

1996 "La Iglesia en el Perú colonial temprano. Fray Jerónimo de Loaysa, primer obispo de Lima". Revista Andina, 27, 1: 53-71.

Acosta, A.

2015 "Iglesia, intereses económicos y teología de la dominación. Contradicciones en la evangelización de la América española. Perú, siglo XVI”. Diálogo Andino, 49: 3-17.

André, M., Romo, J. y Pastora, I.

1848 Diccionario de derecho canónico, tomo IV, Madrid, Imprenta de D. José de la Peña.

André, M., Romo, J. y Pastora, I.

1847-1848 Diccionario de derecho canónico arreglado a la jurisprudencia eclesiástica española antigua y moderna, 4 tomo, Madrid, Imprenta de D. José de la Peña.
Anónimo.

1944 [1600] Historia general de la Compañía de Jesús en la provincia del Perú. II Relaciones de Colegios y Misiones. Edición preparada por F. Mateos, S. J. Madrid, Consejo Superior de Investigaciones Científicas Instituto Gonzalo Fernandez de Oviedo Madrid.

Arias de Ugarte, F.

1629 Constitvciones sinodales del arçobispado de la civdad de la Plata, Prouincia de los Charcas en el Perú, Ciudad de Los Reyes, Jerónimo de Contreras.

Barriera, D.

2006 "Un rostro local de la Monarquía Hispánica: justicia y equipamiento político del territorio al sureste de Charcas, siglos XVI y XVII". Colonial Latin America Historical Review, 15, 4: 377-418.

Bermúdez, J.

1903 Anales de la Catedral de Lima: 1534 a 1824, Lima, Imprenta del Estado. Disponible desde: http://www.cervantesvirtual.com/nd/ark:/59851/bmcqf8p6 
Bergier, N.

1846 Diccionario de Teología, Tomo 3, Madrid, Imprenta de D. Primitivo Fuentes.

Bridikhina, E.

2007 Theatrum mundo. Entramados del poder en Charcas colonial. La Paz, Plural Editores, IFEA.

Campagne, $\mathrm{F}$.

2002 Homo Catholicus. Homo Superstitiosus. El discurso antisupersticioso en la España de los siglos XV a XVIII, Madrid, Miño y Dávila editores / Universidad de Buenos Aires.

Castañeda, P. y Hernández, P.

2007 El II Concilio de la Plata (1774-1778), Madrid, Editorial Deimos.

Castro, N., Chacama J. y Mir, R.

2009 "Excitar y subyugar. Pastoral de la imagen y poblaciones indígenas en Arica Colonial". Diálogo Andino, 34:57-80.

Cavada, C

1986 "Las consuetas de las catedrales de Chile, 1689 y 1744". Revista chilena de historia del derecho, 12:129-154.

Coello de la Rosa, A.

2011 "El Cabildo Catedralicio y los Jueces Adjuntos en Lima Colonial (1601-1611)". Colonial Latin American Review, vol. 20, 3: 331-361.

Covarrubias, $\mathrm{S}$.

1611 Tesoro de la lengua castellana, Madrid, Luis Sánchez. Danwerth, O., Albani, B. y Duve, T. (eds.)

2019 Normatividades e instituciones eclesiásticas en el virreinato del Perú, siglos XVI-XIX, (Global Perspective on Legal History 12), Max Planck Institute for European Legal History, Frankfurt am Maim, http:/dx.doi.org/10.12946/ gplh12

Díaz, J.

2012 "La potestad jurisdiccional del obispo y cabildo catedralicio burgalés durante el siglo XV". Medievalismo, 22: 75-97.

Donoso, J.

1858 Instituciones de derecho canónico americano, tomo I, París, Librería de Rosa y Bouret.

Drapper, L.

2000 Arzobispos, canónigos y sacerdotes: Interacción entre valores religiosos y sociales del clero de Charcas del siglo XVII. Sucre: Archivo-Biblioteca Arquidiocesanos "Monseñor Taborga".

Dussel, E.

1983 Historia general de la Iglesia en América Latina tomo 1/1 Introducción general a la historia de la Iglesia en América Latina. Salamanca: CEHILA/Ediciones Sígueme. Fernández, I.

2010 "La aplicación del Concilio de Trento en las catedrales: el cabildo de Plasencia y el concilio provincial compostelano de 1565". SEMATA, Ciencias Sociais e Humanidades, vol. 22: 195-212.

Figueroa, E.

2021 "El obispo Alonso Granero de Ávalos y las repercusiones locales de su gobierno desde el Memorial de Bartolomé Álvarez. Charcas, 1578-1585". Autoctonía, Revista de Historia y Ciencias Sociales, Vol. 5, n² [en prensa].

Garavaglia, J. y Marchena, J.

2005 América Latina de los orígenes a la independencia. 1. América precolombina y la consolidación del espacio colonial, Barcelona, Crítica.
García, J.

1999 Historia del cabildo metropolitano (1582-1799), Tomo $\mathrm{V}$, Sucre, ABAS.

García, J.

1964 Historia de la Iglesia en La Plata, Obispado de los Charcas, 1553-1609, Arzobispado de La Plata, 1609-1825, Tomo I, Sucre,

Geary, P.

1991 "Mercancías sagradas: La circulación de las reliquias medievales". En Appadurai, A. editor, La vida social de las cosas. Perspectiva cultural de las mercancías, México, Grijalbo, pp. 211-239.

Grignani, M.

2019 "Legislación eclesiástica de Toribio Alfonso de Mogrovejo, segundo arzobispo de Lima: la regla Consueta y los sínodos diocesanos". En Danwerth, O., Albani, B. y Duve, T.(eds.) 2019. Normatividades e instituciones eclesiásticas en el virreinato del Perú, siglos XVI-XIX, (Global Perspective on Legal History 12), Max Planck Institute for European Legal History, Frankfurt am Maim, pp. 19-41.

Grignani, M.

2009 La Regla Consueta de Santo Toribio Mogrovejo y la primera organización de la iglesia americana. Santiago, Ediciones Universidad Católica.

Hampe, T.

1990 "Fray Domingo de Santo Tomás y la encomienda de indios en el Perú". En Barredo, J., editor, Actas del II Congreso Internacional sobre los Dominicos en el Nuevo Mundo, Salamanca, Editorial San Esteban, pp. 355-380.

Herrera, A.

1996 [1638] Relación eclesiástica de la Santa Iglesia Metropolitana de los Charcas, edición de J. Barnadas, Sucre, ABAS.

Iogna-Prat, D.

2016 La invención social de la iglesia en la Edad Media. Buenos Aires, Miño y Dávila Editores.

Lario, D.

2019 Escuelas de Imperio. La formación de una elite en los Colegios Mayores (siglos XVI-XVII). Madrid: Universidad Carlos III de Madrid.

Levillier, R.

1918-1922 Audiencia de Charcas. Correspondencia de presidentes y oidores, 3 tomos, Madrid, Imprenta de Juan Pueyo.

Lobera y Avio, A.

1846 El por qué de todas las ceremonias de la iglesia y sus misterios, París, Librería de A. Mézin.

Martínez, E.

1998 Diccionario de historia moderna de España. I La Iglesia, Madrid, Istmo.

Martínez de Sánchez, A.

2013 "La pena en las consuetas indianas. Los concilios y la redacción de esas normas". Revista de Historia del Derecho, 45: 141-175.

Martínez de Sánchez, A.

2008 "Fuentes de archivo para el estudio del derecho canónico indiano local". Revista de Estudios Histórico-Jurídicos XXX, 2008, pp. 485-503.

Merluzi, M.

2014 Gobernando los Andes. Francisco de Toledo virrey del Perú (1569-1581), Lima, Fondo Editorial Pontificia Universidad Católica del Perú. 
Medina, J.T.

1887 Historia del Tribunal de la Inquisición en Lima (1569-

1820), Tomo I, Santiago, Imprenta Gutemberg.

Ornelas, Marco.

2016 La diferenciación moderna de la religión: la misa latina (1517-1570). México: El Colegio de Sonora / Universidad Iberoamericana.

Oviedo, C.

1986 "Las consuetas de las catedrales de Chile, 1689 y 1744". Revista Chilena de Historia del Derecho, 12, pp. 129-154. Pease, F.

1969 "Una visita al obispado de Charcas (1590)". Humanidades, 3: 89-125.

Pérez, L.

2016a "Una difícil relación. Obispos y cabildos en la creación de los seminarios tridentinos". En Puente, L. y Castillo, J. (coords.) Poder y privilegio: cabildos eclesiásticos en Nueva España, siglos XVI a XIX. México. IISUE-UNAM, pp. 73-90.

Pérez, L.

2016b "Los cabildos de las catedrales indianas, siglos XVI y XVII". Revista Mexicana de Historia del Derecho, XXXII, pp. 23-52.

Pérez, L.

2014 "La reforma regia para el gobierno eclesiástico de las Indias. El libro "de la gobernación espiritual" de Juan de Ovando". En Martínez, M. y Cervantes, F., coords., Reformas y resistencias en la iglesia novohispana, México, Universidad Nacional Autónoma de México / Benemérita Universidad Autónoma de Puebla, pp. 47-76.

Pérez, L.

2013 "Los seminarios tridentinos y la política eclesiástica de Felipe II. El caso de Charcas". Estudios de historia novohispana, 49: 3-38.

Pérez, L.

2005 "El poder de la norma. Los cabildos catedralicios en la legislación conciliar". En Martínez, M. y Cervantes, F., coords., Los concilios provinciales en Nueva España. Reflexiones e influencias, México, Universidad Nacional Autónoma de México /Benemérita Universidad Autónoma de Puebla, pp. 363-388.

Presta, A.M.

2019 "Una elite colonial y sus monjas. Familia y redes en un monasterio de Charcas, 1574-1620". Travesía Revista de Historia Económica y Social, 21, 2: 13-36.

Presta, A.M.

2020 "Ingresos forzados, vocaciones incentivadas y voces desesperadas en el Monasterio de Nuestra Señora de los Remedios de la ciudad de La Plata (Charcas 1574-1640)". Autoctonía. Revista de Ciencias Sociales e Historia, vol. IV, 2: $142-164$.

Presta, A.M.

2021 “Gobierno colonial y gobierno conventual, jerarquías y redes sociales. Una mirada a la sociedad charqueña y al Monasterio de Nuestra Señora de los Remedios de Santa Mónica de la ciudad de La Plata, 1574-1600”. Diálogo Andino, en prensa.

Ramírez del Águila, P.

2017 (1639) Noticias políticas de Indias y relación descriptiva de la ciudad de La Plata, metrópoli de las provincias de los Charcas, edición de Benjamín, N., Sierra, M., Pacheco,

M. y Gantier, B., Sucre, Ciencia Editores.

Real Audiencia de La Plata

2007 Acuerdos de la Real Audiencia de La Plata de los Charcas, 1576-1587, vol. 3, Sucre, Corte Suprema de Justicia de Bolivia/Archivo y Biblioteca Nacionales de Bolivia.

Real Audiencia de La Plata

2007 Acuerdos de la Real Audiencia de La Plata de los Charcas. Servicios y Méritos, 1582-1693, vol. 10, Sucre, Corte Suprema de Justicia de Bolivia/Archivo y Biblioteca Nacionales de Bolivia.

Rico, L.

2019 "Las atribuciones judiciales de los cabildos catedralicios en época moderna. Conflictos y faltas de los capitulares en Salamanca: siglos XVI-XVII". Hispania Sacra, vol. 71, $\mathrm{N}^{\circ} 143$, pp. 233-247.

Rubial, A.

2017 "Íconos vivientes y sabrosos huesos. El papel de los obispos en la construcción del capital simbólico de las episcópolis de Nueva España (1610-1730)”. En Martínez, M. y Cervantes, F., coords., Expresiones y estrategias. La iglesia en el orden social novohispano, México, Universidad Nacional Autónoma de México/Benemérita Universidad Autónoma de Puebla, pp. 217-265.

Sanfuentes, O.

2019 "Un tablado en Belén y una escena de toros en Pachama. Formación de buenos cristianos y apropiación indígena de la evangelización en la pintura mural andina”. Diálogo Andino, 58:43-58.

Schwaller, J.

2016 "El cabildo catedralicio de México en el siglo XVI". En Pérez, L. y Castillo, C.,coords., Poder y privilegio: cabildos eclesiásticos en Nueva España, siglos XVI a XIX, México, Universidad Autónoma de México, pp. 21-48.

Segura, S.

2006 Nuevo diccionario etimológico Latín-Español y de las voces derivadas. Bilbao, Universidad de Deusto.

Solórzano, J.

1648 Política Indiana, Madrid, Diego Díaz de la Carrera.

Terráneo, S.

2018 "Los adjuntos del cabildo en la Diócesis del Antiguo Tucumán (1592-1699)”. Anuario Argentino de Derecho Canónico, 24: 163-180.

Terráneo, $\mathrm{S}$.

2011 "El llamado "III Concilio Provincial Mexicano" y los "Estatutos de la Santa Iglesia de México" o "Reglas consuetas de la catedral de México". Revista de Estudios Histórico-Jurídicos, XXXIII, pp. 613-637.

Tudini, F.

2018 "El arzobispo de Lima Jerónimo de Loayza (15431575), entre el gobierno temporal y el gobierno espiritual". En Pérez, M. y Betrán, J., eds., Nuevas perspectivas de investigación en Historia Moderna: Economía, Sociedad, Política y Cultura en el Mundo Hispánico, Barcelona, Fundación de Historia Moderna /Universidad Autónoma de Barcelona/Universidad de Barcelona, pp. 888-908.

Vallejo, J.

2015 Estudios de Instituciones Hispano-Indianas. II. La Inquisición en Indias. Correo mayor y correos marítimos a Indias. La Real Compañía de Filipinas. Madrid: Agencia Estatal Boletín Oficial del Estado. 
Vargas, R.

1951 Concilios limenses (1551-1772), tomo I, Lima, Tipografía Peruana.

Villarroel, Gaspar.

1738 [1656] Govierno eclesiastico pacifico, y unión de los dos cuchillos pontificio y regio, tomo I, Madrid, Oficina de Antonio Marín.

\section{Fuentes}

Archivo General de Indias (AGI).

Archivo y Biblioteca Arquidiocesanos de Sucre (ABAS).

Archivo y Biblioteca Nacionales de Bolivia (ABNB).

Biblioteca Nacional de España (BNE).

\section{Notas}

1 "Real Cédula al Deán y Cabildo, sede vacante, de la iglesia catedral del obispado de Charca. 30-X-1578", AGI, Charcas 415, L.1, F. 26r-26v.

2 Alonso Maldonado de Torres, Libro de Cédulas y provisiones del rey Nuestro Señor para el gobierno de este reino y provincia, hacienda y patronazgo real, Biblioteca Nacional de España (BNE), Mss 2927, f. 225 r.

3 "Actas capitulares. Sesión 27-VI-1587", Archivo y Biblioteca Arquidiocesanos de Sucre (ABAS), Archivo Capitular (AC), Actas Capitulares, vol. 1, f. 53.

4 "Actas capitulares. Sesión 27-VI-1587“, ABAS, AC, AC, vol. 1, f. 53.

5 Alonso Maldonado de Torres, Libro de Cédulas y provisiones del rey Nuestro Señor para el gobierno de este reino y provincia, hacienda y patronazgo real, Biblioteca Nacional de España, Mss 2927, f. 205 v

6 "Traslado de erección de esta iglesia catedral de la Plata fecha por el R don fray Thomas de San Martín, primer obispo de ella", ABAS, AC, Miscelánea, vol. 2, f. 4 v-5 r.

7 "Carta del obispo Domingo de Santo Tomás. Los Reyes, 6-IV-1567", AGI Charcas 135, 3 r.

8 "Información sobre las doctrinas del obispado de La Plata, ¿1582?”, AGI Charcas 135.

9 "Nombramiento de Francisco de Urquizu. Madrid, 18-II1566", AGI Contratación, 5792, L.1, ff. 35-35v.

10 "Hernando de Palacio Alvarado", AGI, Indiferente, 2080, N. 9 , f. 1.

11 "Nombramiento de Hernando de Palacio Alvarado. Madrid, 10-III-1567”, AGI, Contratación, 5792, L. 1, f. 45 v-46 r.

12 "Real cédula al doctor Hernando de palacio Alvarado, clérigo presbítero, arcediano de la iglesia catedral de La Plata de los Charcas. Madrid, 30-VIII-1567”, AGI Charcas 418, L. 1, ff. $124 \mathrm{v}-125 \mathrm{r}$.

13 "Información sobre las doctrinas del obispado de La Plata, ¿1582?”, AGI Charcas 135.

14 “Actas capitulares", ABAS, AC, vo. 1, f. 55. García (1999: 18) señala como deán a Fernando Márquez de Sotomayor.

15 AGI, Indiferente, 2856, L. 3, f. 63-64.

16 AGI, Indiferente, 2856, L. 3, f. 63. En la designación de Juan de Resa, realizada en 1586, se remarcó que la canonjía "está vaca en la forma ordinaria".

17 AGI, Indiferente, 2856, L. 3, f. 62.

18 AGI, Indiferente, 2856, L. 3, f. 66.

19 “Actas capitulares. Sesión 18-IV-1597”, ABAS, AC, vol. 1, f. 185 [186].

20 “Actas capitulares. Sesión 3-II-1595”, ABAS, AC, vol. 1, f. 163 [164].

21 "Diego Felipe de Molina", AGI, Contratación 5268, N. 1, R. 44.

22 Alonso Maldonado de Torres, Libro de Cédulas y provisiones del rey Nuestro Señor para el gobierno de este reino y provincia, hacienda y patronazgo real, Biblioteca Nacional de España, Mss 2927, f. 205 v.

23 “Actas capitulares. 31-V-1596”, ABAS, AC, AC, vol. 1, f. 180 [181].

24 "Actas Capitulares", ABAS, AC, AC, vol. 1, f. 1.

25 "Actas Capitulares", ABAS, AC, AC, vol. 1, f. 20-21. Esto último es bastante llamativo, pues el provisor, designado por un obispado, tenía la facultad de conocer las causas civiles y criminales que afectaban a los capitulares, además, de proveer y quitar vicarías y doctrinas. Aunque para la revisión de causas que involucraban a los capitulares se procedió a elegir anualmente a dos jueces consiliarios.

26 "Actas capitulares", ABAS, AC, AC, vol. 1 f. 50.

27 Alonso Maldonado de Torres, Libro de Cédulas y provisiones del rey Nuestro Señor para el gobierno de este reino y provincia, hacienda y patronazgo real, Biblioteca Nacional de España, Mss 2927, f. 226 v- 227 r.

28 "Actas Capitulares", ABAS, AC, AC, vol. 1, f. 98.

29 El cabildo es "un ayuntamiento, o congregación, assi de eclesiasticos como seglares" (Covarrubias 1611: 164).

30 "Actas capitulares", ABAS, AC, AC, vol. 1, f. 99.

31 "Actas capitulares", ABAS, AC. AC, vol. 1, f. 100.

32 "Actas capitulares", ABAS, AC, AC, vol. 1, f. 61. Se trata del capítulo 33 De reformatione, Constituciones de Españoles, II Concilio Limense, en el que se advertía que la pérdida de la disciplina tenía consecuencias nocivas en la vida de los fieles, por lo que resultaba imprescindible reformar las conductas del clero (Vargas 1951; I: 117).

33 Para un análisis socio histórico del convento de los Remedios en La Plata, consúltese Presta (2019, 2020, 2021).

34 “Actas capitulares. Sesión 26-IV-1594”, ABAS, AC, AC, vol. 1, f. 137 [139] - 139 [140].

35 “Actas Capitulares. Sesión 30-I-1587”, ABAS, AC, AC, vol. 1, f. 41.

36 “Actas capitulares. Sesión 22-III-1596”, ABAS, AC, AC, vol. 1, f. 176 [177].

37 Alonso Maldonado de Torres, Libro de Cédulas y provisiones del rey Nuestro Señor para el gobierno de este reino y provincia, hacienda y patronazgo real, Biblioteca Nacional de España, Mss 2927, f. 199 v - 200 r.

38 "Carta de la Audiencia de Charcas a S. M. refiriendo los inconvenientes que ofrece el quedar vacantes los obispados de aquel reino". La Plata, 3 de octubre de 1587", Levillier (1922; II: 312-313).

39 AGI, Patronato, 248, R. 8.

40 "Carta de la Audiencia de Charcas a S.M. sobre las presentaciones para beneficios y doctrinas y renuncias de oficiales de escribanos de cámara. La Plata 26 de septiembre de 1591", en Levillier (1922; III: 131).

41 “Actas capitulares. Sesión 16-XII-1585”, ABAS, AC, AC, vol. 1 , f. 24. 
42 “Actas capitulares. Sesión 30-VII-1593”, ABAS, AC. AC, vol. 1 , f. 125.

43 Actas capitulares. Sesión 30-VII-1593", ABAS, AC, AC, vol. 1 , f. 125 .

44 "Traslado de erección de esta iglesia catedral de la Plata fecha por el R. don fray Thomas de San Martín, primer obispo de ella", ABAS, AC, Miscelánea, vol. 2, f. 4 v - 5 r.

45 "Consulta al Consejo de Indias. 16-1-1578”, AGI, Indiferente General 739, N 46.

46 "Carta del doctor Diego Felipe de Molina chantre de la Catedral de La Plata al virrey del Perú. Informa que siendo presidente del cabildo en sede vacante fue puesto en prisión con gran escándalo por dicho Cabildo al ir a dar el sermón de san Tomás de Aquino. La Plata, 3-IV-1594”, ABNB, Correspondencia Audiencia de Charcas (CACh) 182, f. 1 r.

47 En 1599, fecha de esta relación de la audiencia, Diego Felipe de Molina se encontraba en España y solo pudo viajar a Charcas en 1602 (AGI, Contratación, 5268, N. 1, R. 44). Por lo que es posible que la mención que se hace a los conflictos del chantre con el deán corresponda a conflictos pasados.

48 "Carta del deán Francisco Vásquez Sotomayor. La Plata, 8 de marzo de 1588", AGI, Charcas 16, R 27, N. 158, f. 1 r-v.

49 "Carta del deán Francisco Vásquez Sotomayor. La Plata, 8 de marzo de 1588", AGI, Charcas 16, R 27, N. 158, f. 1 v.

50 “Actas capitulares. Sesión 17-VII-1587”, ABAS, AC, AC, vol. 1 , f. 56.

51 “Actas capitulares. Sesión 10-XI-1587”, ABAS, AC, AC, vol. 1, f. 59. El informe de esta visita fue publicado por Pease (1969), y es el único que se conoce hasta ahora sobre estas visitas en el obispado de La Plata. En febrero de 1588, Diego Felipe de Molina informó de los buenos efectos que tuvo su visita y pretendió llevar la visita en persona al Consejo, pero fue conminado a que la remitiese y retornase a sus obligaciones en el cabildo de la iglesia catedral. "Real cédula al doctor Diego Felipe de Molina, chantre de la iglesia catedral de la ciudad de La Plata. 18-I-1589", AGI Charcas 415, L. 2, folio 85 v.

52 “Actas capitulares. Sesión 9-VI-1589”, ABAS, AC, AC, vol. 1, f. 79.

53 "Actas capitulares. Sesión 4-I-1594", ABAS, AC, AC, vol. 1, f. 130-136.

54 “Actas capitulares. Sesión 16-I-1595”, ABAS, AC, AC, vol. 1, f. 154 [155].

55 "Relación del viaje de fray Diego de Ocaña por el Nuevo Mundo (1599-1605)", Fondo Antiguo Universidad de Oviedo, Manuscrito 215.

56 "Relación del viaje de fray Diego de Ocaña por el Nuevo Mundo (1599-1605)", Fondo Antiguo Universidad de Oviedo, Manuscrito 215, f. 214 r.

57 "Relación del viaje de fray Diego de Ocaña por el Nuevo Mundo (1599-1605)", Fondo Antiguo Universidad de Oviedo, Manuscrito 215, f. 218 r.

58 "Relación del viaje de fray Diego de Ocaña por el Nuevo Mundo (1599-1605)", Fondo Antiguo Universidad de Oviedo, Manuscrito 215, f. 216 r.

59 “Actas capitulares. Sesión 14-III-1598", ABAS, AC, AC, vol. 1, f. 220 [221].

60 En ocasiones, para esto recurrieron al remate de algunos bienes de la capilla. En 1606, se remató la tapicería de boscaje (paisaje de árboles, animales y matorrales) cuyo dinero se utilizó para mandar a pintar cuatro cuadros consagrados a San Ildefonso.

61 "Actas capitulares. Sesión 23-XI-1601”, ABAS, AC, AC, vol. 1 , f. 377.

62 "Relación del viaje de fray Diego de Ocaña por el Nuevo Mundo (1599-1605)", Fondo Antiguo Universidad de Oviedo, Manuscrito 215, f. 217 r.

63 "Relación del viaje de fray Diego de Ocaña por el Nuevo Mundo (1599-1605)", Fondo Antiguo Universidad de Oviedo, Manuscrito 215, f. 217 v.

64 "Carta a S. M. del Licenciado Cepeda, contestando a varias cedulas reales y dando cuenta de lo acertado que sería el llevar esclavos a aquellas partes para prosperidad de la tierra y labor de minas. La Plata 28 Febrero 1590", Levillier (1922; III: 22).

65 "Carta a V. M. del nuevo oidor doctor Arias de Ugarte dando cuenta del estado en que hallo la Audiencia de Charcas. Acompañan memorial de los Indios de su distrito en razón de los agravios que reciben. Pide que se tomen medidas para que no desembarquen extranjeros y gente perdida por el puerto de Buenos Ayres. Potosí 28 de Febrero de 1599", Levillier (1922; III: 355).

66 "Regla consueta formada por los ilustrísimos y reverendísimos padres que componen el concilio provincial que se celebra en la metropolitana de La Plata (1778)", ABAS, AC, Miscelánea, vol. 3. En esta Regla Consueta se incorporaron varias disposiciones de la erección de 1553 y de las Constituciones de 1597.

67 "Constituciones originales de la Yglesia de la Plata hechas por el señor obispo don Alonso Ramires de Bergara, 1597", ABAS, AC, Varios, vol. 2, f. 4 r.

68 "Constituciones originales de la Yglesia de la Plata hechas por el señor obispo don Alonso Ramires de Bergara, 1597", ABAS, AC, Varios, vol. 2, f.

69 "Constituciones originales de la Yglesia de la Plata hechas por el señor obispo don Alonso Ramires de Bergara, 1597", ABAS, AC, Varios, vol. 2, f. $21 \mathrm{v}^{\circ}$.

70 "Erección, constituciones y regla consueta de esta iglesia catedral metropolitana de La Plata", Archivo Histórico Casa de la Libertad, C 1.1.13, n. 76. Según el catálogo del archivo, esta copia perteneció a Bernardino Méndez de Parra, prebendado de la iglesia catedral. De acuerdo con García, el presbítero Bernardino Méndez de la Parra figura en el período 1784-1791 como medio racionero del cabildo de la iglesia catedral de La Plata; mientras que el período 1791-1796 figura como racionero; y en 1798 fue posesionado como canónigo doctoral (García 1999: 153, 160 y 162 ).

71 "Constituciones originales de la Yglesia de la Plata hechas por el señor obispo don Alonso Ramires de Bergara, 1597”, ABAS, AC, Varios, vol. 2, f. 4 v.

72 “Actas capitulares. Sesión 12-III-1587”, ABAS. AC, AC, vol. 1, f. 43.

73 "Carta a S M de D. Lope Diez de Armendaris, Presidente de la Audiencia de Charcas. La Plata, 25-IX-1576", Levillier (1918; I: 341-342).

74 "El obispo de Quito sobre diversos asuntos", AGI, Quito 77 , N. 31 , f. $1 \mathrm{v}$.

75 “Actas capitulares. Sesión 6-V-1597”, ABAS, AC, AC, vol. 1, f. 188 [189]-192 [193].

76 “Actas capitulares. Sesión 25-I-1600", ABAS, AC, AC, vol. 1, f. 298 [299]. 